\title{
Biotic changes around the radioisotopically constrained Carboniferous-Permian boundary in the Boskovice Basin (Czech Republic)
}

\author{
STANISLAV OPLUŠTIL, JAKUB JIRÁSEK, MARK SCHMITZ \& DALIBOR MATÝSEK
}

\begin{abstract}
Presented is an analysis of vegetation patterns across the Carboniferous-Permian boundary in continental setting constrained for the first time in Europe and North America by high-precision U-Pb radioisotopic dating. The analysis is performed on the fossil record of the Boskovice Basin (Czech Republic), a Late Palaeozoic half-graben having $5 \mathrm{~km}$ of cumulative thickness. It is dominantly a red bed succession containing numerous grey, mostly lacustrine horizons bearing fairly rich fossil floras and faunas of Late Pennsylvanian to Cisuralian age. U-Pb geochronology on single zircon crystals separated from a volcanic tuff near the top of the Rosice-Oslavany Formation, in the lower part of the basin succession, provided an age of $298.88 \pm 0.09 \mathrm{Ma}$, that nearly exactly corresponds to the Carboniferous-Permian boundary as currently accepted in the International Chronostratigraphic Chart v2016/04. The upper part of the basin fill is correlated via fish faunas with the Intra-Sudetic and Krkonoše-Piedmont basins, where embedded volcanic rocks provided late Asselian ages. The succession of the Boskovice Basin records a well-known aridification trend demonstrated by the transition from Gzhelian coal-bearing sediments of the Rosice-Oslavany Formation to Asselian red beds. This trend is interrupted by grey lacustrine horizons, which represent major windows of preservation formed during more humid intervals. Vegetation patterns show the transition from assemblages dominated by free-sporing plants, mostly tree ferns, typical of Late Pennsylvanian wetlands, to peltasperm-walchian conifers dominated assemblages of the Cisuralian. Similar transition has been observed also in coeval succession of the Intra-Sudetic Basin and elsewhere in the former central and western equatorial Pangea. - Key words: Boskovice Basin, Carboniferous, Permian, flora, fauna, radioisotopic age, climate.
\end{abstract}

\begin{abstract}
OPLUŠTIL, S., JIRÁSEK, J., SCHMITZ, M. \& MATÝSEK, D. 2017. Biotic changes around the radioisotopically constrained Carboniferous-Permian boundary in the Boskovice Basin (Czech Republic). Bulletin of Geosciences 92(1), 95-122 (14 figures, 1 table). Czech Geological Survey, Prague. ISSN 1214-1119. Manuscript received September 29, 2016; accepted in revised form January 12, 2017; published online March 31, 2017; issued March 31, 2017.

Stanislav Opluštil, Department of Geology and Palaeontology, Charles University, Faculty of Science, Albertov 6, 128 43, Prague 2, Czech Republic; oplustil@natur.cuni.cz•Jakub Jirásek, VŠB-Technical University of Ostrava, Faculty of Mining and Geology, 17. listopadu 15/2172, 70833 Ostrava-Poruba, Czech Republic; jakub.jirasek@vsb.cz. - Mark Schmitz, Department of Geosciences, Boise State University, Boise, Idaho 83725, USA; markschmitz@boisestate.edu・Dalibor Matýsek, VŠB - Technical University of Ostrava, Faculty of Mining and Geology, 17. listopadu 15/2172, 70833 Ostrava-Poruba, Czech Republic; dalibor.matysek@vsb.cz.
\end{abstract}

Increasing aridification at the end of the Pennsylvanian and beginning of the Permian led to the nearly complete disappearance of peat-forming wetlands in central and western tropical Pangea. This change in turn affected the composition of flora and resulted in complex changes from typical wetland vegetation composed of cryptogams (free-sporing plants) and early gymnosperms, to more water-deficiency-tolerant vegetation dominated by gymnosperms, mostly peltasperms and conifers (e.g. Gothan 1912, DiMichele et al. 2008). Climatic changes on several time scales (Cecil 1990, Driese \& Ober 2005, Roscher \& Schneider 2006, Tabor \& Poulsen 2008, Cecil et al. 2014, DiMichele 2014) and the overall low potential of preservation of or- ganic matter, especially that of plants, results in a spatiotemporally discontinuous fossil record concentrated mostly in windows of preservation, and thus makes the precise recognition of the Carboniferous-Permian boundary even more complicated (Broutin et al. 1986, 1990; DiMichele et al. 2008). This is further amplified by absence of any typical guide plant fossil(s) marking the boundary. For a long time, the onset of the "callipteris" flora was taken as a base of the Permian Stage, as well as the boundary between the Palaeophyticum and Mesophyticum (e.g. Goeppert 1858, Geinitz 1865, Gothan 1912, Havlena 1964), until callipterids were found in the Stephanian stratotype in the French Massif Central (Bourouz \& Doubinger 1977). 
Callipterids have subsequently been discovered in evidently Late Pennsylvanian strata at a number of localities in Europe, North America and North Africa (Broutin et al. 1986, 1990; Kerp 1988, 1996; Lyons \& Darrah 1989; DiMichele \& Aronson 1992; Hmich et al. 2006; DiMichele et al. 2008, 2013; Wagner \& Álvarez-Vázquez 2010; Pšenička et al. 2011; DiMichele 2014). In contrast, the Carboniferous-Permian boundary in purely continental settings could be better constrained by insect and conchostracan biostratigraphy, which are in places directly linked by conodont biostratigraphy to the Global Marine Standard Scale (e.g. Schneider et al. 2013, Lucas et al. 2016, Schneider \& Scholze 2016).

The onset of aridification (or tectonically improved basin drainage and, in turn, substrate dryness - see Cleal et al. 2010, 2011 for details) becomes obvious at around the Middle-Late Pennsylvanian transition and is marked by intrabiomic changes in dominancy patterns of wetland floras, specifically a drastic decrease in dominancy and diversity of arborescent lycopsids and their replacement by maratiallean ferns (Pfefferkorn \& Thomson 1982, Phillips et al. 1985, Cleal et al. 2010). Throughout the Late Pennsylvanian, the climate became more seasonal and formerly widespread wetlands were spatially restricted, and in basinal lowlands flora adapted to water deficiency (e.g. walchian conifers and later also callipterids) appeared for the first time. Around the Carboniferous-Permian boundary the climatic aridification resulted in the further decline of remaining peat-forming wetlands in most of central and western tropical Pangea. Climatic and related environmental changes resulted in more profound vegetational reorganization, characterised by interbiomic transition (e.g. DiMichele et al. 2006, DiMichele 2014) recognized already by Gothan (1912) and again by Kerp (1996) as a transition from the Palaeophyticum to the Mesophyticum. Due to local differences in climate and environments and high-frequency climatic oscillations superimposed on an overall aridification trend (Roscher \& Schneider 2006, Tabor \& Poulsen 2008), this transition is spatially and temporarily complex, and in the continental setting led to problems of precise location of the Carboniferous-Permian boundary by macrofloral biostratigraphy (for overview see DiMichele et al. 2006, 2008; DiMichele 2014). Detailed studies of floras from particular basins are therefore required to better understand spatio-temporal variability of these changes across the former tropical Pangea. In the Boskovice Basin, which is one of Late
Palaeozoic continental basins in the Czech Republic, a new high precision radioisotopic datum constrains the position of the Carboniferous-Permian boundary, and thus for the first time allows us to characterize in detail vegetational changes across this critical time interval in this basin as a good example of the Central European basins in general.

\section{Geology and lithostratigraphy of the Boskovice Basin}

The Boskovice Basin is nearly a $100 \mathrm{~km}$ long and 3 to $10 \mathrm{~km}$ wide, NNE-SSW striking half-graben situated in the eastern part of the Bohemian Massif at the boundary between Lugo-Danubicum and Moravo-Silesicum (Fig. 1). Its purely continental deposition started in the late Gzhelian (late Stephanian) in southern part of the basin, and without any detected interruption continued in northern part until Cisuralian times (Pešek et al. 2001). The basin depocentre is divided into southern and northern sub-basins, separated by a zone of reduced thickness called the Tišnov-Kuřim Elevation (Havlena 1964, Malý in Pešek et al. 2001). In the older southern Rosice-Oslavany Sub-basin sedimentation started in the late Stephanian and lasted till the "Autunian". The northern Letovice Sub-basin was established in the early "Autunian" and deposition here continued probably up to the early "Saxonian" (Kozur 1980). After Schneider and Werneburg (2012) and Schneider et al. (2014) the depositional history of the basin lasted from the latest Kasimovian to the earliest Kungurian. The composite sedimentary record in both depocentres is estimated by Jaroš (1962) to about 5000 to $6000 \mathrm{~m}$, although seismic data show that the maximum thickness of the sub-basins does not exceed 2000 m (Malý 1993). Deposition during most of the sedimentary history was triggered by the Main Fault of the Boskovice Basin situated along its eastern margin (Fig. 2), generating diachronous coarse-grained facies of the Rokytná Conglomerate interpreted as an alluvial fan system (e.g. Jaroš 1962, Melichar 1995).

Sedimentary fill of the basin is divided into four formations (Fig. 3). The two oldest formations, the RosiceOslavany and Padochov, fill the southern sub-basin whereas the remaining two younger formations, the Veverská Bítýška and Letovice, are present only in the northern Letovice Sub-basin (Pešek et al. 2001, Pešek 2004).

Figure 1. A - the Late Paleozoic continental basins in the Czech Republic (basins: PB - Pilsen, MB - Manětín, RB - Radnice, ŽB - Žihle, KRB - Kladno-Rakovník, MRB - Mšeno-Roudnice, ČKB - Česká Kamenice, MHB - Mnichovo Hradiště, KPB - Krkonoše-Piedmont, ISB - Intra-Sudetic, BB - Blanice, OB - Orlice). $\bullet B$ - the Boskovice Basin with indication of the Rosice-Oslavany and Letovice sub-basins. $\bullet \mathrm{C}-$ detailed geological map of the Rosice-Oslavany Sub-basin (after Jaroš 1962). Note the gradual approaching of the lacustrine horizons to the western basin margin marking the gradual opening of the depocentre of the sub-basin. 


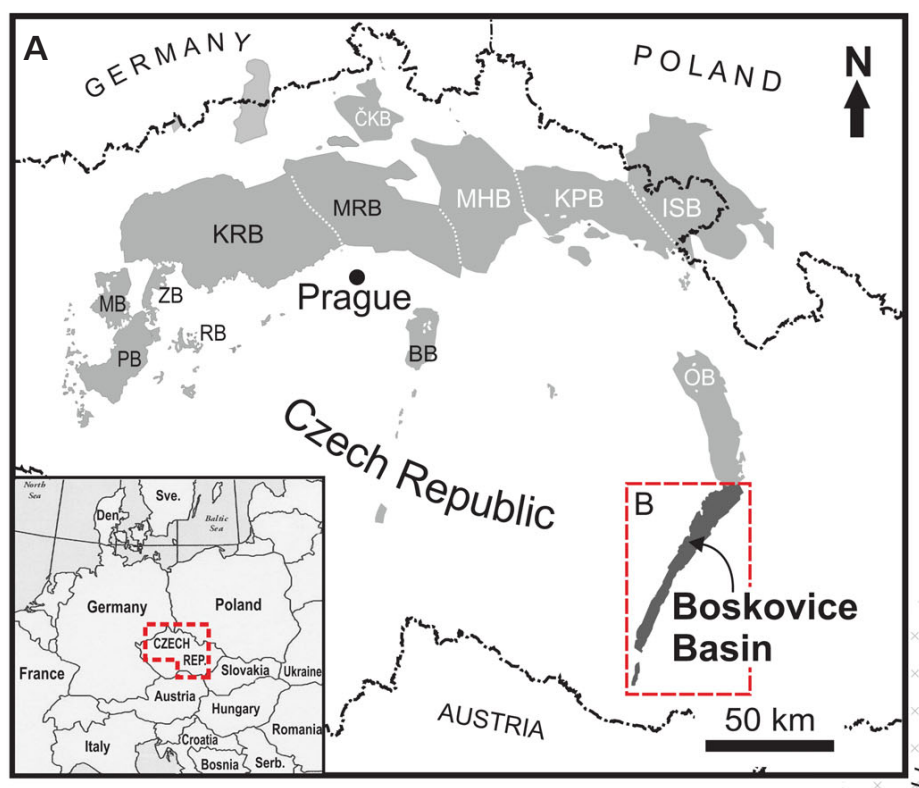

B

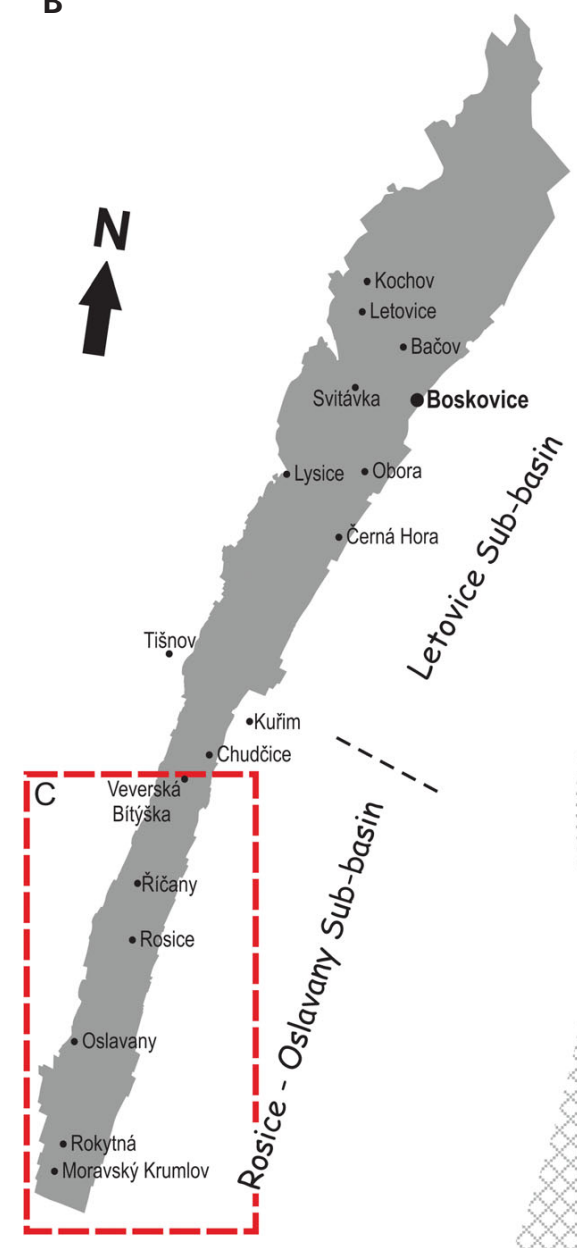

$10 \mathrm{~km}$
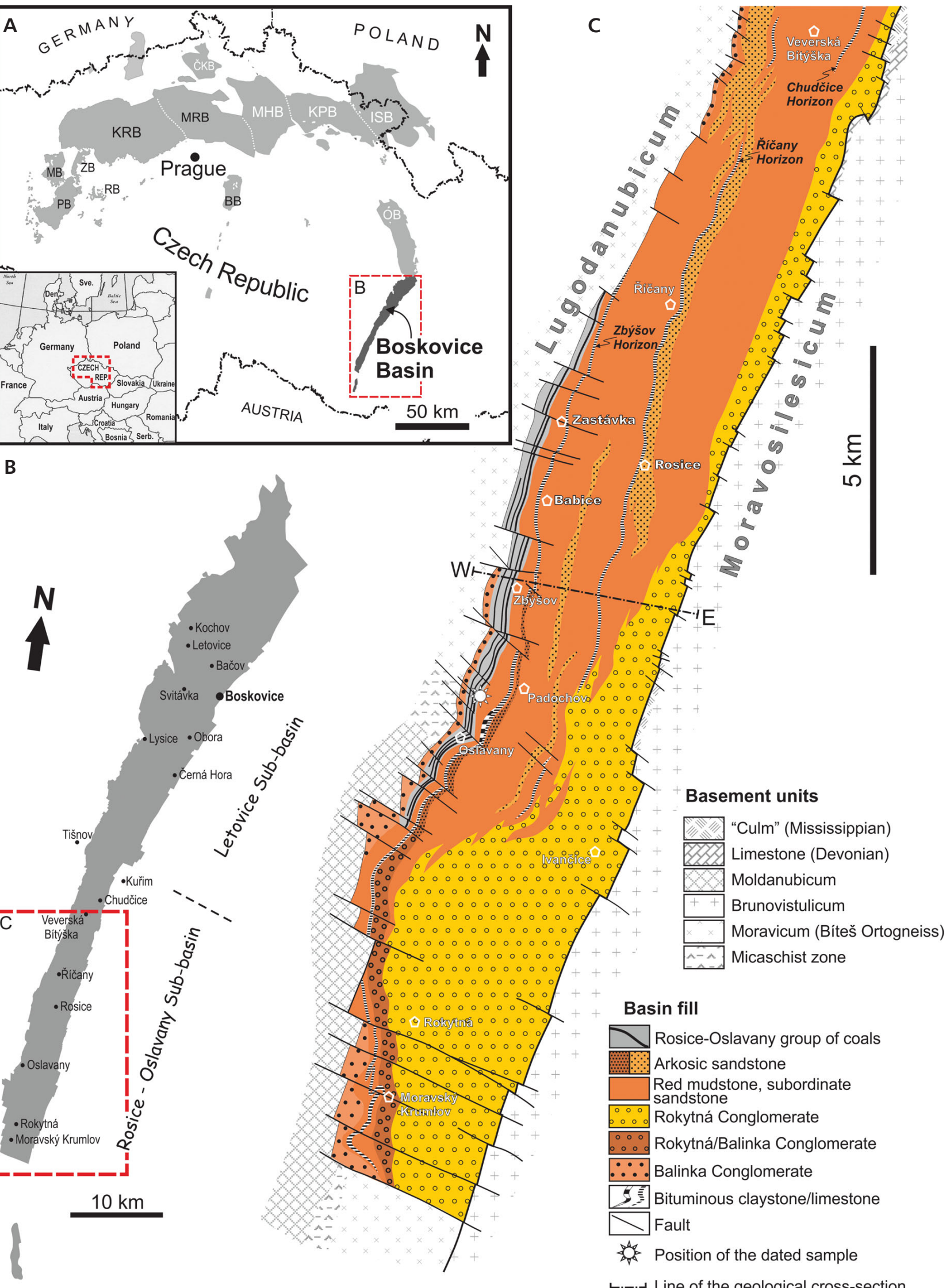


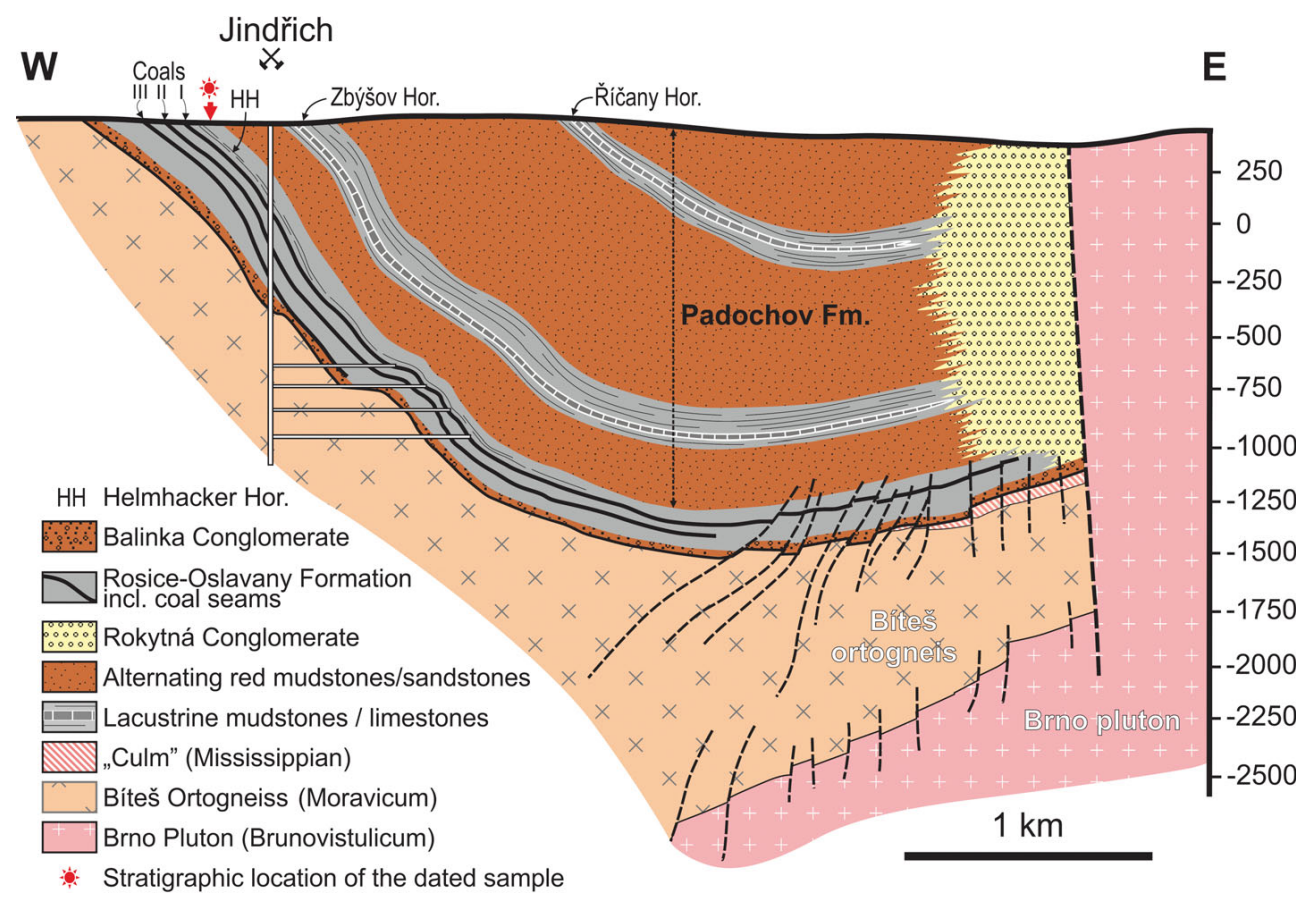

Figure 2. The W-E geological section across the southern part of the Boskovice Basin showing the half-graben basin geometry (according to Malý 1993 and Buriánek et al. 2011). For position of the cross-section see the Figure 1C.

\section{The Rosice-Oslavany Formation (late Gzhelian-early Asselian)}

Deposition of this up to 300 m thick unit took place only in the southern Rosice-Oslavany Sub-basin. Its thickness is affected by basement palaeotopography, further amplified by syndepositional activity of faults (Malý 1993). Its basal part is dominantly represented by coarse-grained facies of the Balinka Conglomerate of local provenance, the thickness of which depends on pre-sedimentary palaeotopography and varies from a few to as much as $75 \mathrm{~m}$ (Jaroš 1962). Higher in the section the proportion of conglomerate significantly decreases in favour of red-brown sandstone and mudstone. This "red" part of the formation grades upward into a $120 \mathrm{~m}$ thick complex of mostly grey strata, which bear three economically important coals of the Rosice-Oslavany group numbered from top to bottom as the coals Nos I, II and III; 1.5-6.5 m, 0.8-2.4 m and 0.8-1.4 m thick, respectively (Fig. 3). Accompanying clastic sediments include mudstones and sandstones alternating with subordinate conglomerates. Locally present between coals, especially between the Coal I and Coal II are red clastic sedimentary rocks. Their areal extent corresponds to increasing ash content in the Coal I (Malý 1993). About $20 \mathrm{~m}$ above the Coal I is the few metres thick lacustrine Helmhacker Horizon, which has provided allochtonous flora (Helmhacker 1866, Rieger 1965). The remaining about $40 \mathrm{~m}$ thick uppermost part of the Rosice-Oslavany Formation consists of alternating mudstones and sandstones locally with thin non-workable coals near the top of the formation.

\section{The Padochov Formation (early Asselian)}

This early "Autunian" lithostratigraphic unit is restricted to the Rosice-Oslavany Sub-basin, where its deposition continued without an interruption from the Rosice-Oslavany Formation (Figs 3, 4). It is a $1200 \mathrm{~m}$ thick red bed succession composed of alternating sandstones (locally feldspathic) and mudstones, in which are embedded two few to tens of metres thick grey lacustrine horizons bearing a rich fossil record. Stratigraphically older is the Zbýšov Horizon, situated $\sim 50 \mathrm{~m}$ above the base of the formation. It is a $\sim 60 \mathrm{~m}$ thick complex of grey sandstones, mudstones and claystone with a 3-to-4-m-thick horizon of bituminous carbonate. About 900 m higher, near top of the formation is the Říčany Horizon, composed of grey mudstones, claystones and a bed of lacustrine carbonate. Different sedimentation characterised the eastern basin margin, where intensive subsidence along an active fault resulted in deposition of the coarse-grained Rokytná Conglomerate composed of cobbles derived from an eastward-located source area (Pešek et al. 2001).

\section{Veverská Bítýška Formation (Asselian)}

This unit is $\mathrm{a} \sim 1500 \mathrm{~m}$ thick complex of dominantly red sandstones and mudstones. Locally present grey strata consist of lacustrine mudstones, claystones, and embedded thin intercalations of clayey limestones. The most prominent grey interval is the Chudčice Horizon near the top of the formation. Unfortunately, no fossils have been found in 
this formation. Its deposition is concentrated in the northern Letovice Sub-basin.

\section{Letovice Formation (Asselian)}

Deposition of this up to $3000 \mathrm{~m}$ unit (Pešek et al. 2001) took place only in the northern Letovice Sub-basin (Figs 3, 4). The age of unit is not satisfactorily resolved and differs by author and study. Kozur (1980) and Pešek et al. (2001) suggested a late Autunian to early Saxonian age whereas Šimůnek \& Martínek (2009) and Schneider \& Werneburg (2012) interpreted a Sakmarian to Artinskian age for the formation. In contrast Štamberg (2014), based on duration of fish zones, believes that the upper part of the formation is still of Asselian age. The formation consists of red and grey clastics, the latter ones mostly represented by lacustrine sediments concentrated into nine horizons (Pešek et al. 2001). Some of them provide an important fossil record including fish, amphibians, insects, and plant fossils. In the central and western part of the basin the formation consists of red fluvial sediments including sandstone (locally feldspathic) and mudstones; conglomerates are subordinate. Sediments alternate in a cyclic pattern except in the eastern part, where the formation is represented by the Rokytná Conglomerate deposited along the eastern tectonic margin of the basin.

\section{Volcanic rocks of the Boskovice Basin}

Volcanic rocks in the Boskovice Basin were described as keratophyres by Gartner (1924), Zapletal (1925), Zapletal \& Locker (1930) and Malý $(1968,1972)$. These were interpreted mostly as dykes that cut sediments of the Rosice-Oslavany Formation and stratigraphically adjacent part of red "Permian" sandstones. Přichystal (1993, 1994) used the TAS classification to describe some of them as basic andesites, trachyandesites, and subalkaline dacites. Most are very fine-grained rocks with pale colours, forming both concordant and discordant veins up to $1.5 \mathrm{~m}$ thick. They consist mostly of feldspars with oligoclase to albite composition and show typical alterations such as calcitization, chloritization of biotite, and epidotization of plagioclase. Volcaniclastic rocks were described by Králík \& Malý (1987) from the Jindřich Mine in Zbýšov. Tuffs or more possibly tuffites form horizons of 10 to $50 \mathrm{~cm}$ thickness in sediments surrounding Coal III, and possibly also Coal I.

Figure 3. Lithostratigraphic subdivision of the Boskovice Basin succession. According to Jaroš (1962) and Pešek et al. (2001). Abbreviation: R-O F. - Rosice-Oslavany Formation.

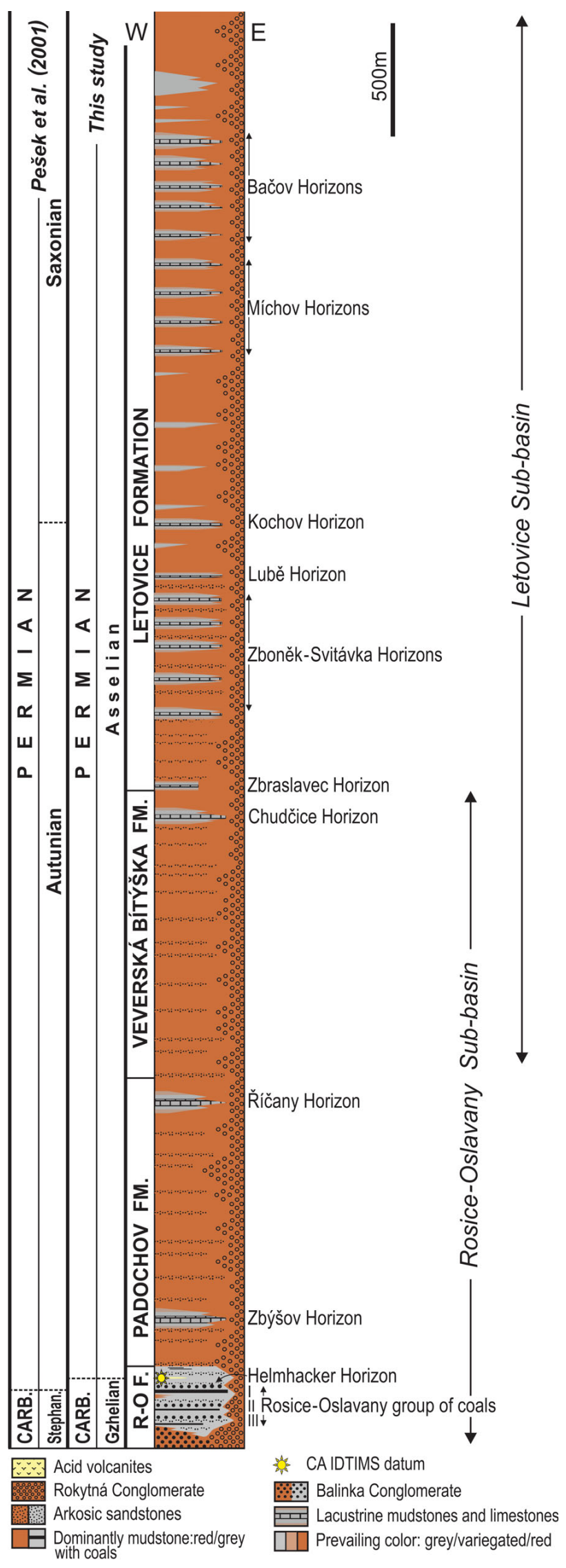




\section{History of stratigraphic research in the Boskovice Basin}

The beginning of systematic research dates back to the first half of the $19^{\text {th }}$ century when coal exploitation in the southern part of the basin was established. Besides data from coal mines, important information has been obtained from outcrops, including the section along the Oslava River near Oslavany. It exposes the transition of late Gzhelian to early Asselian strata and has been a matter of several detailed studies (e.g. Jaroš 1962, Šimůnek \& Martínek 2009).

Since the early research in the Boskovice Basin, a fairly large number of authors have contributed to our current knowledge on basin geology and stratigraphy. Detailed overviews of the history of the basin research are provided in the papers of Augusta (1933a, 1937a), Havlena (1955), Šimůnek \& Martínek (2009) and partly also in Pešek (2004). Here we only briefly summarize the opinions on age of strata as developed since the earliest times of investigation. Among the earliest authors who dealt with basin stratigraphy were Zippe (1835, 1842) and Rittler (1853) who correlated coal seams of the Rosice-Oslavany group and overlying strata with the Rotliegend from Germany. In contrast Beyrich (1844) and Hingenau (1852) considered these coals to be Carboniferous. Reuss (1854) believed that the Rotliegend is represented by red sediments above the coal group; however, he did not stated the age of the coal seams below. Geinitz (1865) was first to prove a Carboniferous age of the coal group from the character of flora, and correlated it with Ottweiller Member in the Saar Basin. This conclusion was further supported by Helmhacker (1866), who considered the flora in the roof of the Coal No. I as being typically Carboniferous. However, $\sim 20 \mathrm{~m}$ above that coal he found a plant-bearing horizon (now called the Helmhacker Horizon), which provided a mixture of typically Carboniferous or Permian species and therefore concluded that no sharp boundary exists between the Carboniferous and Permian part of the basin succession. In contrast, Stur (1873) put the Carboniferous-Permian (C-P) boundary in close proximity above the Coal I, where he found Autunia conferta Sternberg, considered by Goeppert (1858) as a typical Rotliegend species in Germany. Later, however, Feistmantel (1883) reinterpreted the flora of the Rosice-Oslavany coal group as Permian. This conclusion was later supported also by Katzer (1895) and Kušta (1900). This concept was questioned and subsequently abandoned when Weithofer $(1902,1903)$ interpreted the age of coals of the Rosice-Oslavany group as Carboniferous. Later papers concentrated mostly on systematic palaeobotanical research of the thick red bed complex and embedded grey lacustrine strata considered since the $19^{\text {th }}$ century as Permian (e.g. Augusta 1926, 1927, 1928, 1929, 1931a, b, 1934, 1935, 1937b, 1946, 1949; Havlena \& Špinar 1956). The precise position of the C-P boundary was discussed in the second half of the $20^{\text {th }}$ century by several authors. Němejc $(1951,1953)$ considered all three major coals as Carboniferous despite the fact that a rare occurrence of Autunia conferta has been known from a clastic parting in the Coal I. However, he did not suggest any precise boundary between Carboniferous and Permian. In contrast Havlena (1964) for the same reason located the C-P boundary at the base of the Coal I. This argument was, however, questioned, when Bouroz \& Doubinger (1977), and also other authors, described Autunia conferta from the Stephanian stratotype and from Stephanian strata elsewhere (Wagner \& Álvarez-Vázquez 2010). Later Rieger (1965) collected flora from the shaft Jindřich in Zbýšov across the assumed C-P boundary and found several Callipterid species in the level of the Helmhacker Horizon about $22 \mathrm{~m}$ above the Coal I, but no such species in close proximity above that coal, as did Němejc (1951) and Šetlík (1951) in coal mine Ferdinand near Babice. However, no precise position of the C-P boundary was suggested. Currently the C-P boundary was placed by Šimůnek (2003) into the roof of the Helmhacker Horizon. Šimůnek in Pešek et al. (2001) provided the first list of plant fossils identified in the Boskovice Basin, which was later updated and extended by newly collected material (Šimůnek \& Martínek 2009).

Apart from the intensive palaeobotanical research in the Boskovice Basin nearly no palynological data exist from this basin due to its high coal rank (Pešek et al. 2001). The only exception is a miospore assemblage from the Ŕícany Horizon in the upper part of the Padochov Formation of early Permian ("Autunian") age (Zajíc et al. 1996). The assemblage in the lower part of this horizon is dominated by trilete spores $(\sim 90 \%)$, especially of Crassispora plicata, C. sp. and Lycospora pussila, Reistrickia saetosa, Leiotriletes minutus, L. sphaerotriangularis and Calamospora breviradiata. In the upper part of the same horizon, however, $\sim 80 \%$ of the spores are of monosaccate pollen genera Potoniesporites and Florinites. Common are also Illinites, Gardanaisporites, Alisporites, Protohaploxipinus. Subordinate are Crassispora, Calamospora spp., Laevigatosporites minutus and L. medius.

The Boskovice Basin is also well-known for its faunal remains (see Štamberg \& Zajíc 2008 for an overview), both vertebrates (fish, amphibians, and exceptionally also reptiles) and invertebrates (mainly insects). Systematic research of fauna started in the first half of the $20^{\text {th }}$ century and continues through the present (Augusta 1926, 1931c, 1933b; Špinar 1951, 1952a, b, 1959; Kukalová 1955, 1963, 1964, 1965; Schneider 1980, 1984; Klembara 1997; Klembara \& Meszaros 1992; Klembara \& Bartík 1999; Zajíc 2000; Zajíc \& Štamberg 2004; Štamberg 2007, 2013a, b, 2014; Schneider \& Werneburg 2012). Most of the faunal remains occur in the Permian part of the basin succession. Therefore, the role of fauna in stratigraphic re- 


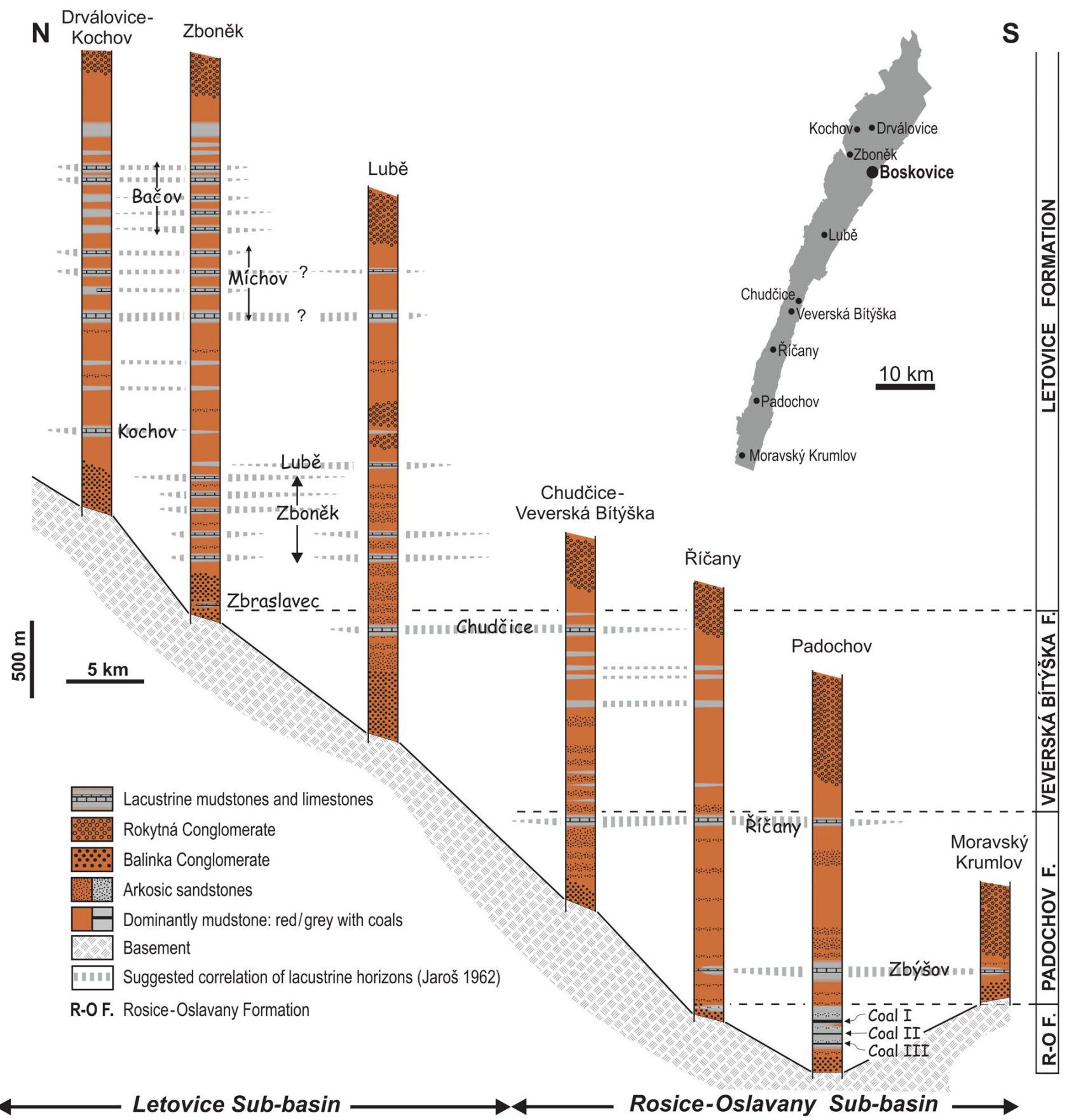

Figure 4. The N-S schematic section of the Boskovice Basin with correlation of the grey mostly lacustrine horizons as suggested by Jaroš (1962). Note the depocentre migration to the north. Modified after Pešek et al. (2001).

search on the position of C-P boundary has played so far a less important role.

\section{Biostratigraphy of the Boskovice Basin}

Fossil remains in the sedimentary fill of the Boskovice Basin, concerning its quantity and quality of preservation, are spatially and temporarily unevenly distributed, mainly as a consequence of changes in fossilization potential triggered by variations in ground-water table. The major windows of preservation in the Carboniferous part of the basin succession are grey strata of the Rosice-Oslavany coal group, especially roof shales and some clastic partings embedded in coals. In the Permian part of the succession the major fossil-bearing intervals are grey, usually several 
metres to a few tens of metres thick lacustrine horizons embedded in fluvial red beds (Šimůnek \& Martínek 2009). The hundreds of metres thick red beds bear mostly only poorly preserved impressions of walchian conifers or cordaites (Rieger 1965). Although subordinate in volume and irregular in stratigraphic distribution, the fossiliferous horizons cover nearly the whole range of the basin stratigraphy and thus provide valuable information about the floral and faunal dynamics and compositional changes throughout the late Gzhelian to Cisuralian times.

Of key importance for the older part of the basin fill is macroflora, the character of which allows for its assignment to the existing floral zones (Wagner 1984, Wagner \& Álvarez-Vázquez 2010). In the Permian part of the basin succession, however, the floral zones become less reliable, whereas the importance of fauna for biostratigraphy significantly increases (e.g. Zajíc 2000; Schneider \& Werneburg 2012; Stamberg 2013a, 2014).

\section{Macroflora}

The oldest flora of the Boskovice Basin is that of the Rosice-Oslavany Formation, where it has been collected mostly from mudstones accompanying coals and from the Helmhacker Horizon about $20 \mathrm{~m}$ above the Coal I. All three coals of the Rosice-Oslavany group are accompanied by peat-forming flora (summarised in Fig. 5) with only minor differences between individual seams (Šimůnek in Pešek et al. 2001, Šimůnek \& Martínek 2009). The assemblage is typically dominated by pecopterids and pteridosperms (Šimůnek \& Martínek 2009). Stratigraphically important species include Sphenophyllum angustifolium (Germar) Goeppert, Sphenopteris mathetii Zeiller, Pseudomariopteris busquetii (Zeiller) Danze-Corsin, P. densifolia Goeppert (Weiss), Alethopteris zeilleri (Ragot) Wagner, Odontopteris schlotheimii Brongniart and Neurocallipteris neuropteroides (Goeppert) Cleal, Shute et Zodrow.

Šimůnek \& Martínek (2009) documented spatial differences in time-equivalent floras from various localities ranging from typically "hygrophilous" dominated by pteridosperms, calamites and ferns to more "xerophilous" where wetland taxa are subordinate to conifers and cordaites. Although temporal differences are minor, worth noting is an absence of Sphenophyllum angustifolium and the presence of some new species in proximity to the Coal I: Autunia conferta, A. naumannii (Gutbier) Kerp, Dichophyllum flabelliferum (Weiss) Kerp et Hauboldt, Lodevia nicklesii Zeiller (Hauboldt et Kerp), “Callipteris” zbejsovensis Augusta, Sphenopteris germanica Weiss, Culmitzschia speciosa (Florin) Clement-Westerhof, Ernestiodendron filiciforme (Schlotheim) Florin, Walchia goeppertiana (Florin) Clement-Westerhof and W. pini- formis Sternberg. Remains of these species were found in discrete layers mostly separately from hygrophilous floras, although stratigraphically in their very close proximity (Němejc 1951, Rieger 1965, Šimůnek \& Martínek 2009). Their fragmentary nature led the authors to the conclusion that these species were transported into the depocentre from habitats situated above the basin lowland. A similar but poorer assemblage is also known from the Helmhacker Horizon (Helmhacker 1866, Rieger 1965), where identified were Odontopteris schlotheimii, Sphenopteris germanica, Autunia conferta, A. naumannii, Dichophyllum flabelliferum, Ernestiodendron filiciforme and Walchia sp. According to Šimůnek in Pešek et al. (2001) and Šimůnek \& Martínek (2009) the lower part of the formation up to the Coal II belongs to the Sphenophyllum angustifolium Zone, whereas the remaining part of the formation represents Autunia conferta Zone.

The flora of the following Padochov Formation is known mainly from the lacustrine Zbýšov and Říčany horizons. The former horizon provided diverse (Fig. 5) pteridosperm-conifer dominated plant assemblage (Šimůnek \& Martínek 2009). The newly appearing species are Arnhardtia scheibei (Gothan) Hauboldt et Kerp, Rhachiphyllum curretiensis (Zeiller) Kerp, R. lyratifolia (Goeppert) Kerp, Taeniopteris abnormis Gutbier, Otovicia hypnoides (Brongniart) Kerp, Carpentieria marocana Němejc et Augusta, Pterophyllum sp., Zamites sp. whereas Dichophyllum flabelliferum, Lodevia nicklesii and "Callipteris" zbejsovensis have their last occurrence in this horizon. Flora of the Ř́čany Horizon in the upper part of the formation is similar but less diverse than that of the Zbýšov Horizon (Fig. 5). Overlying the Padochov Formation is the Veverská Bítýška Formation containing the Chudčice Horizon of lacustrine origin that provided only poor conifer-dominated assemblage (Šimůnek \& Martínek 2009).

In the youngest Letovice Formation up to nine grey lacustrine horizons have been distinguished by Jaroš (in Pešek et al. 2001). Flora has been found in the Zbraslavec, Zboněk-Svitávka, Lubě, Kochov, Míchov and Bačov horizons. The Zbraslavec Horizon provided only a low diversity assemblage (Fig. 5) with predominance of pteridosperms and conifers. Relatively diverse assemblage is known also from the Zboněk-Svitávka Horizon where Culmitzschia frondosa (Renault) Clement-Westerhof and C. hirmeri (Florin) Clement-Westerhof occur for the first time (Fig. 5). Fossil record of the horizon is dominated by remains of walchian conifers and of peltasperms of the genus Autunia (Šimůnek \& Martínek 2009; Schneider personal communication). Floras of the youngest lacustrine horizons, the Kochov, Míchov and Bačov, are very similar (Fig. 5) including dominancy of walchian conifers and peltasperms (Šimůnek \& Martínek 2009), which is in agreement with their position within a narrow stratigraphic interval. Among species that newly appear at this level 
Figure 5. Stratigraphic ranges of plant taxa identified in the Boskovice Basin. Based on data from Šimůnek \& Martínek (2009) and Pešek et al. (2001). Abbreviations: R-O F. - Rosice-Oslavany Formation, g. c. group of coals, D.f. Dichophyllum flabelliferum, A.c. - Autunia conferta, S.a. - Sphenophyllum angustifolium.

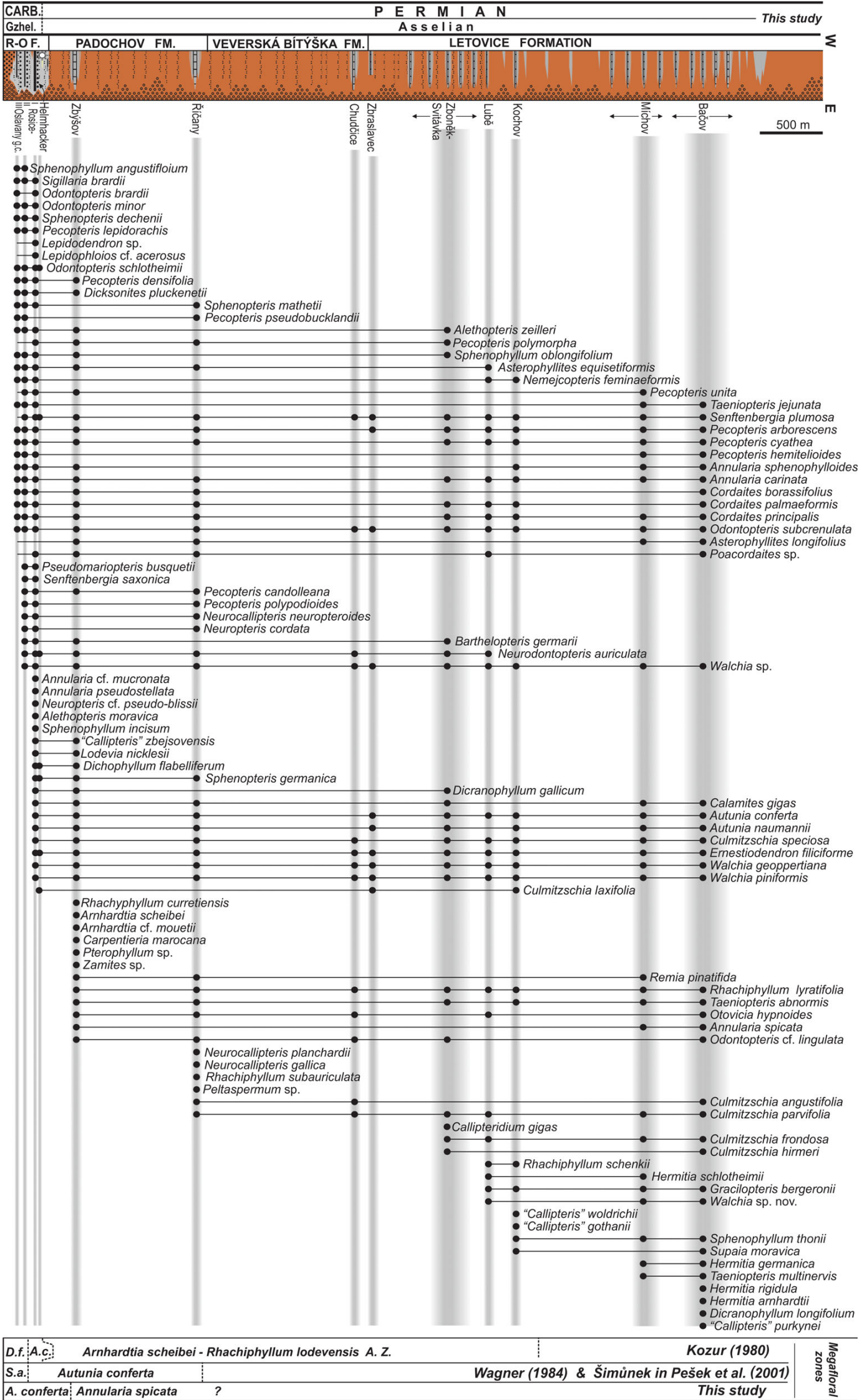




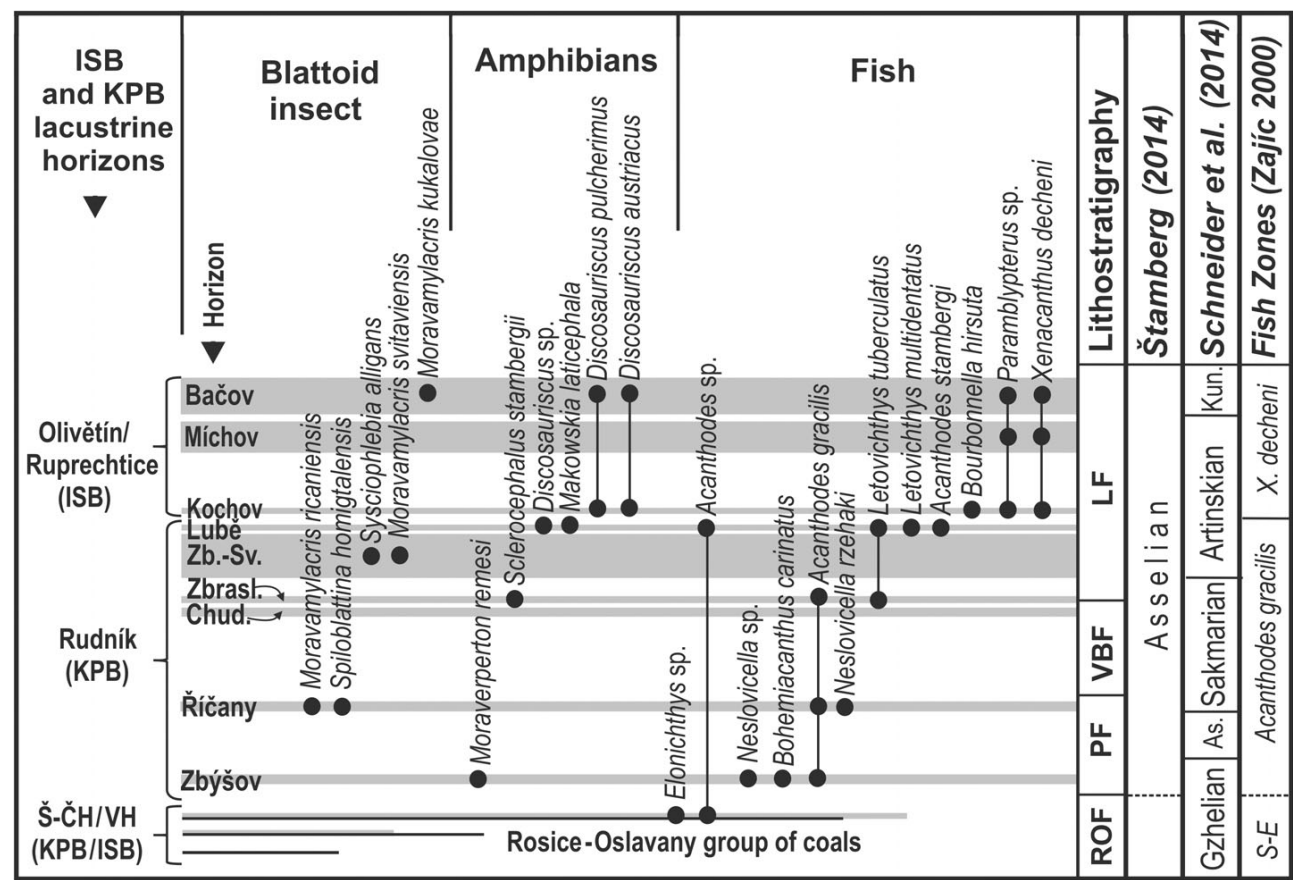

Figure 6. Selected faunal species and their stratigraphic ranges in the Boskovice Basin.

Formations: ROF - Rosice-Oslavany, PF - Padochov, VBF - Veverská Bíty̌ška, LF - Letovice; Zb.-Sv. - Zboněk-Svitávka Horizon Lacustrine horizons Coal As. - Asselian, Kun. - Kungurian, S-E - Sphaerolepis-Elonichthys Zone ISB - Intra-Sudetic Basin, KPB - Krkonoše-Piedmont Basin, Š-ČH/VH - Štěpanice-Čikvásky Horizon/Vernéřovice Horizon

mentioned should be Supaia moravica Němejc et Augusta, Sphenophyllum thonii Mahr and several species of the conifer genus Hermitia (Fig. 5).

\section{Fauna}

Only sporadic fauna have been found in the RosiceOslavany Formation in grey mudstones surrounding coals (Fig. 6). Invertebrates are represented by insect wings of Anthracoblattina sp. (Schneider 1983). Vertebrates are represented by small fragment of a pelycosaur reptile ?Edaphosaurus sp. (Prantl 1943) and actinopterygian scales including Elonichthys krejci, indicating the local bio/ecozone Sphaerolepis-Elonichthys and consequently a late Stephanian (Gzhelian) age (Zajíc 2000, 2004, 2005).

The fauna of the Padochov Formation is concentrated in the Zbýšov and Říčany lacustrine horizons. Common for both horizons is Acanthodes gracilis, which indicates a position in the local bio/ecozone of the same name and is thus equivalent to the Rudník Horizon in the Krkonoše-Piedmont Basin (Zajíc 2004, 2005; Opluštil et al. 2013; Stamberg 2014). An important representative of this biozone is the shark Bohemiacanthus carinatus. In the Zbýšov Horizon present also are amphibians Moraverpeton remesi, ?Branchiosaurus sp., and ?Pelosaurus sp. (Štamberg \& Zajíc 2008, Opluštil et al. 2013). Invertebrates are represented by pelecypods Carbonicola thuringensis, C. remesi, Palaeanodonta sophiae, P. com- pressa, P. verneuili and P. castor (Opluštil et al. 2013). Conchostracan remains probably belong to the family Lioestheriidae (Opluštil et al. 2013). The insect fauna is diverse and includes Moraviptera reticulata, Opsiomylacris cf. procera, Phyloblatta flabellata, Phyloblatta moravica, Phyloblatta sp., Kashmiroblatta sp., Blattinopsis antoniana, and Permoedischia moravica (Schneider 1980, 1983, 1984). In the Říčany Horizon no pelecypods have been found yet; however conchostracans of Lioestheriidae indet. occur. The remarkably diversified entomofauna is represented by Moravamylacris ricanyensis, Phyloblatta flabelata, $P$. cf. curvata, $P$. dyadica, Spiloblattina homigtalensis, Poroblattina rotundata, Blattinopsis angustai, B. latissima, B. campestris, B. martynovae, Blattinopsis sp., and Pseudomerope gallei and others (Kukalová 1959, 1965; Schneider 1980, 1984; Schneider \& Werneburg 2012). Vertebrates are represented by Acanthodes sp., and by actinopterygian fish Neslovicella rzehaki and Actinopterygii indet. (Fig. 6; Štamberg \& Zajíc 2008).

So far no fauna has been found in the Veverská Bítýška Formation. However, rich fauna is known from the lacustrine horizons of the youngest Letovice Formation. In its lower part there are the Zbraslavec, Zboněk-Svitávka and Lubě horizons, the fish fauna of which is uniform for all these horizons and indicate their position within the local Acanthodes gracilis Zone. Present also are two actinopterygian species Letovichthys tuberculatus and L. multidentatus (Štamberg 2007). Insects are common and include stratigraphically important taxa Sysciophlebia 
alligans, Opsimylacris svitavensis and Moravamylacris sp. (Schneider \& Werneburg 2006, 2012).

Faunas are relative uniform in the remaining Kochov, Míchov and Bačov lacustrine horizons in the middle and upper parts of the Letovice Formation. Besides conchostracans, invertebrates are represented by diversified entomofauna. World-famous is the Obora locality in the Bačov Horizon, from where Kukalová $(1963,1964)$ and Schneider $(1980,1984)$ described about 100 insect species. Vertebrates are represented by the index biozone shark taxon Xenacanthus decheni. Actinopterigians include common Paramblypterus "type B" accompanied in the Kochov Horizon by rare Bourbonnella hirsuta (Štamberg 2014). Amphibians are represented by genera Discosauriscus and Letoverpeton (Špinar 1952a).

\section{Material and methods}

The sample of the radioisotopically dated volcaniclastic rock was taken from a small natural outcrop (GPS: $\mathrm{N} 49^{\circ}$ 08.053 $\mathrm{E} 016^{\circ} 20.484^{\prime}$ ) situated along southern slope of the Balinka Creek valley about $1200 \mathrm{~m}$ ENE of the town of Oslavany and $700 \mathrm{~m}$ WSW of the village of Padochov (Figs 7, 8).

Separation of zircons and their radiometric dating was done in the Isotope Geology Laboratory of the Boise State University, Idaho. A heavy mineral separate containing abundant moderate to highly elongated, prismatic zircon crystals was separated by conventional density and magnetic methods. The bulk zircon separate was annealed in a muffle furnace at $900{ }^{\circ} \mathrm{C}$ for 60 hours in quartz beakers prepare the crystals for subsequent chemical abrasion (Mattinson 2005). Individual crystals were hand-picked and chemically abraded using a single aggressive abrasion step in concentrated $\mathrm{HF}$ at $190{ }^{\circ} \mathrm{C}$ for 12 hours, and the residual crystals processed for isotope dilution thermal ionization mass spectrometry (ID-TIMS). Single crystals were spiked with the ET535 mixed U-Pb spike, with internal U fractionation correction and $\mathrm{Pb}$ fractionation corrected using an externally-derived mass bias derived from the average $\mathrm{Pb}$ fractionation of ET2535-spiked samples analysed over the same experimental interval. The details of ID-TIMS analysis are described by Davydov et al. (2010) and Schmitz \& Davydov (2012). U-Pb dates and uncertainties for each analysis were calculated using the algorithms of Schmitz \& Schoene (2007), the U decay constants of Jaffey et al. (1971), and the ET535 spike composition of Condon et al. (2007). The quoted uncertainties in Table 1 are based upon non-systematic analytical errors, including counting statistics, instrumental fractionation, tracer subtraction, and blank subtraction. These error estimates should be considered when comparing our ${ }^{206} \mathrm{~Pb} /{ }^{238} \mathrm{U}$ dates with those from other laboratories that used tracer solutions

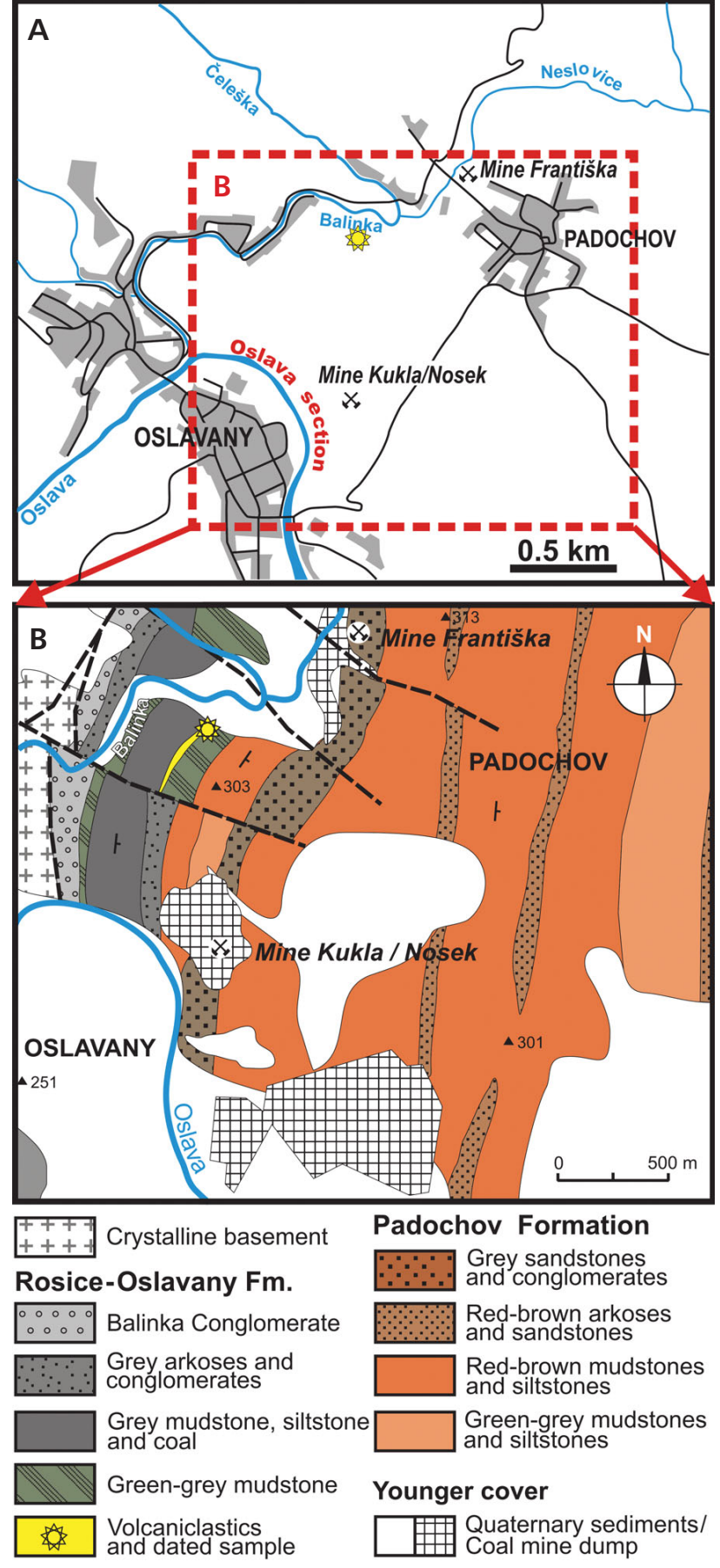

Figure 7. A- location of the dated sample of volcanite, and B - its stratigraphical position in a geological map (Buriánek et al. 2011).

calibrated against the EARTHTIME gravimetric standards. When comparing our dates with those derived from other decay schemes (e.g. $\left.{ }^{40} \mathrm{Ar} /{ }^{39} \mathrm{Ar},{ }^{187} \mathrm{Re}^{-187} \mathrm{Os}\right)$, the uncertainties in tracer calibration $(0.03 \%$; McLean et al. 2015) and U decay constants (0.108\%; Jaffey et al. 1971) should be added to the internal error in quadrature. Interpreted sample ages are thus reported as $\pm \mathrm{X}(\mathrm{Y})[\mathrm{Z}] \mathrm{Ma}$, 

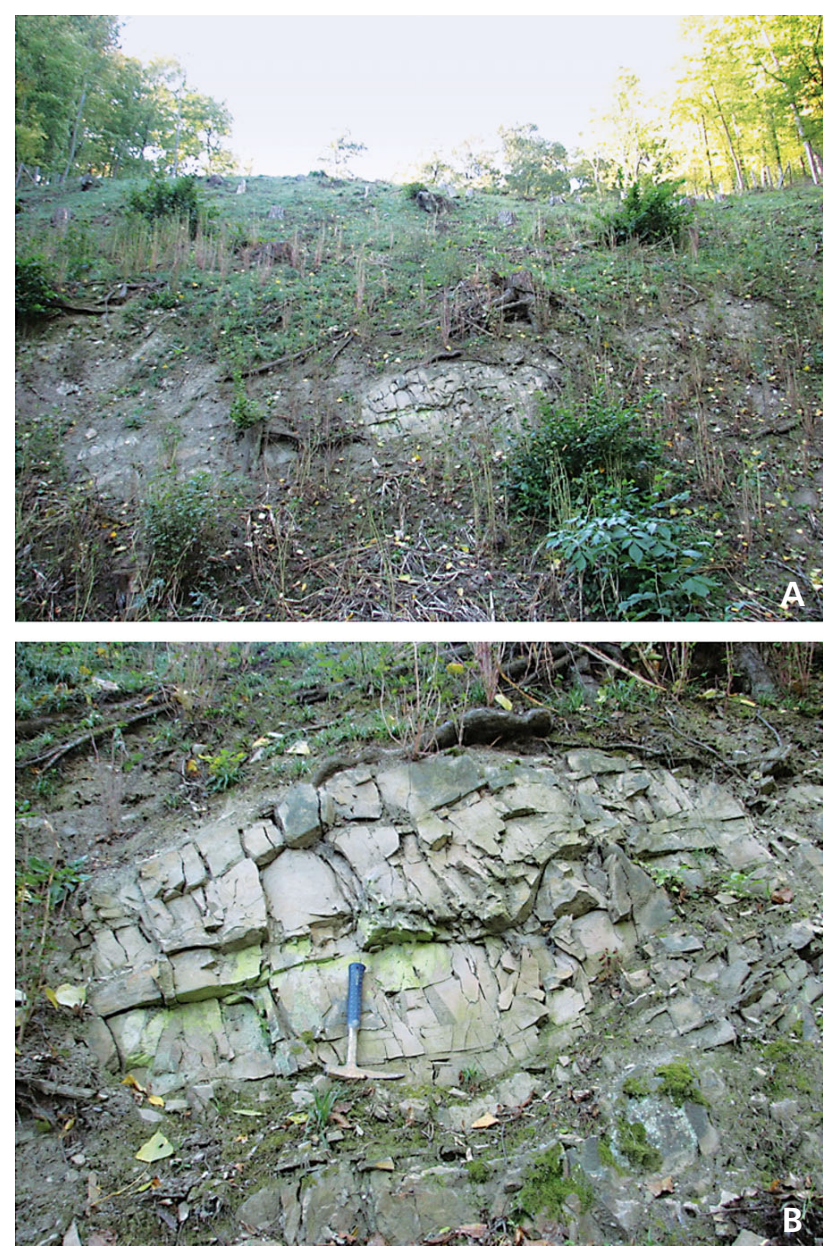

Figure 8. Dated volcanic rocks embedded in sediments in top of the Rosice-Oslavany Formation.

where $\mathrm{X}$ is the internal error, $\mathrm{Y}$ is the internal plus tracer calibration error, and $\mathrm{Z}$ is the internal plus tracer plus decay constant uncertainty.

In addition to the radioisotopic age measurements, the volcanite was studied also petrographically and mineralogically using microscopic methods, X-ray diffraction, and bulk chemical analyses. Microscopic investigation and EDX microanalysis of the tuff components were carried out on an electron microscope (model FEI Quanta 650 FEG) equipped with various detectors (EDX-EDAX Galaxy, WDA-EDAX LEXSY, and CL-Gatan Mono 4 CL). Analyses were made using polished thin sections that were coated with a $10 \mathrm{~nm}$ thin film of carbon under the following conditions: $15 \mathrm{kV}$ beam voltage $(30 \mathrm{kV}$ in some cases for emission line $\mathrm{Sr}$ $\mathrm{K} \alpha), 8-10 \mathrm{nA}$ current, 6 or $4.5 \mu \mathrm{m}$ beam diameter, and a high vacuum exceeding $10^{-3} \mathrm{~Pa}$. Identification and quantification of spectral lines was performed using the decomposition method by means of halographic peak deconvolution (EDAX 2003).
Powder X-ray diffraction analyzes were carried out using a Bruker-AXS D8 Advance instrument with a $2 \Theta / \Theta$ measurement geometry and the positionally sensitive detector LynxEye under the following conditions: radiation $\mathrm{CoK} \alpha / \mathrm{Fe}$ filter, current $40 \mathrm{kV}, 40 \mathrm{~mA}$ voltage, step mode with a step of $0.014^{\circ} 2 \Theta$, and a total time of 25 seconds per step. Qualitative analysis of diffraction patterns was performed using the EVA software (Bruker-AXS) and the database PDF-2, release 2011 (International Centre for Diffraction Data). The Rietveld method using the TOPAS software, version 4.2 (Bruker) was applied to verify the qualitative analyses and to quantify the mineral phases present.

For bulk chemical analyses, we selected a representative rock sample collected in 2016 weighing approximately $100 \mathrm{~g}$. The chemical analyses were performed at the Bureau Veritas Mineral Laboratories in Vancouver, Canada. The sample was crushed, pulverised to 200 mesh and reduced in weight by quartering. Aliquots for analyses of the standard oxides were dissolved in hot $\left(95^{\circ} \mathrm{C}\right)$ aqua regia and analysed using Inductively Coupled Plasma Optical Emission Spectroscopy (ICP-OES).

Analysis of vegetation diversity and pattern is based on data published by Šimůnek in Pešek et al. (2001) and by Šimůnek \& Martínek (2009), where nomenclatorically and taxonomically upgraded lists of plant species identified so far in the basin were published. Individual taxa were plotted against the stratigraphic chart. Ranges of taxa are inferred from their presence/absence in particular stratigraphic levels. If a taxon is missing from any level and has been found below and above that level, it is accepted as occurring here (Cleal 2005).

This approach allows for more meaningful recognition of plant diversity throughout the basin succession. This analysis, in turn, also requires the minimum number of organs approach, based on estimation of number of biological species from organ types that best characterize individual plant groups. As an example, diversity of pteridosperms or ferns in compression state of preservation is best expressed by their foliage. This method avoids the inflation of diversity and is commonly used in similar palaeobotanical studies (e.g. Cleal 2005, Cleal et al. 2012). Data were further used for constrained cluster analysis using a Raup-Crick coefficient and the PAST software (Hammer et al. 2001).

\section{Results}

\section{Stratigraphic position of the volcanic body}

The dated sample of volcaniclastic rock was taken from $\mathrm{a} \sim 2 \mathrm{~m}$ thick volcanic body that is embedded in a succession of irregularly alternating green-grey mudstones silt- 


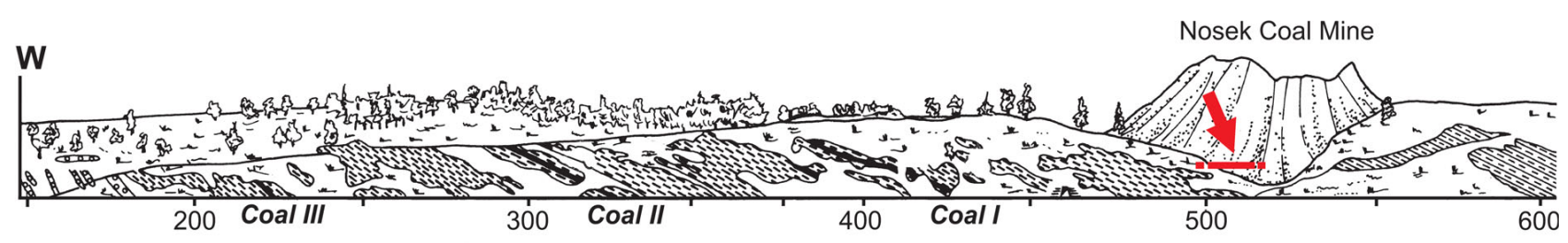

$\because 0 \%$ Red beds with Balínka Conglomerate

E

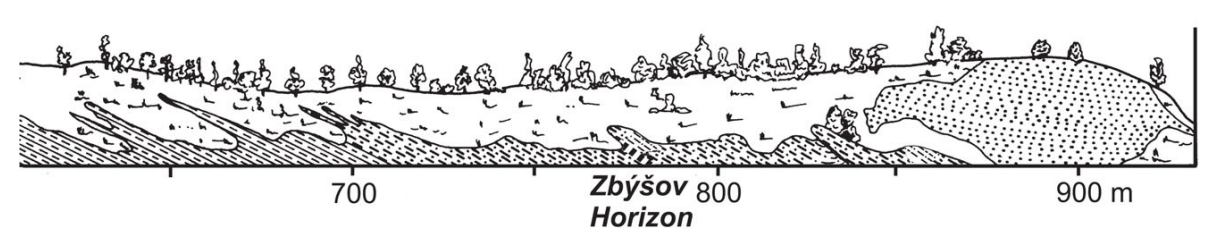

Gey beds with coal seams

Figure 9. Schematic section of strata exposed along the Oslava River (for location see the Fig. 7). Arrow indicates approximate stratigraphic position of the embedded volcanic rock. Modified after Pešek et al. 2001.

Table 1. U-Pb Isotopic Data of the Oslavany tuffite. Abbreviations: (a) z1, z2, etc. are labels for single zircon grains or fragments chemically abraded at $190^{\circ} \mathrm{C}$; analyses in bold used in the weighted mean calculations. (b) Model Th/ $\mathrm{U}$ ratio calculated from radiogenic ${ }^{208} \mathrm{~Pb} /{ }^{206} \mathrm{~Pb}$ ratio and ${ }^{207} \mathrm{~Pb} /{ }^{235} \mathrm{U}$ date. (c) $\mathrm{Pb} *$ and $\mathrm{Pbc}$ are radiogenic and common $\mathrm{Pb}$, respectively. mol\% ${ }^{206} \mathrm{~Pb} *$ is with respect to radiogenic and blank $\mathrm{Pb}$. (d) Measured ratio corrected for spike and fractionation only. Samples were spiked with the ET535 tracer, with an external Pb fractionation correction of $0.20 \pm 0.03(1-\sigma) \% /$ amu (atomic mass unit), based on analysis of NBS-981 and NBS-982. (e) Corrected for fractionation, spike, common Pb, and initial disequilibrium in ${ }^{230} \mathrm{Th} /{ }^{238} \mathrm{U}$. Up to $0.5 \mathrm{pg}$ of common $\mathrm{Pb}$ is assigned to procedural blank with composition of ${ }^{206} \mathrm{~Pb} /{ }^{204} \mathrm{~Pb}=18.042 \pm 0.61 ;{ }^{207} \mathrm{~Pb} /{ }^{204} \mathrm{~Pb}=15.537 \pm 0.52$; ${ }^{208} \mathrm{~Pb} /{ }^{204} \mathrm{~Pb}=37.686 \pm 0.63(1-\sigma)$. Excess over blank was assigned to initial common $\mathrm{Pb}$, using the Stacey \& Kramers (1975) two-stage $\mathrm{Pb}$ isotope evolution model at $300 \mathrm{Ma}$. (f) Errors are 2- $\sigma$, propagated using algorithms of Schmitz \& Schoene (2007). (g) Calculations based on the decay constants of Jaffey et al. $1971 .{ }^{206} \mathrm{~Pb} /{ }^{238} \mathrm{U}$ and ${ }^{207} \mathrm{~Pb} /{ }^{206} \mathrm{~Pb}$ ratios and dates corrected for initial disequilibrium in ${ }^{230} \mathrm{Th} /{ }^{238} \mathrm{U}$ using Th/U $[\mathrm{magma}]=3$.

\begin{tabular}{|c|c|c|c|c|c|c|c|c|c|c|c|c|c|c|c|c|c|c|c|c|}
\hline \multirow[b]{2}{*}{ Grain } & \multirow[b]{2}{*}{$\frac{\mathrm{Th}}{\mathrm{U}}$} & \multirow[b]{2}{*}{$\begin{array}{c}{ }^{206} \mathrm{~Pb}^{*} \\
\mathrm{x} 10^{-13} \mathrm{~mol} \\
\end{array}$} & \multirow[b]{2}{*}{$\begin{array}{l}{ }_{206} \mathrm{~Pb}^{*} \\
\end{array}$} & \multirow[b]{2}{*}{$\frac{\mathrm{Pb}^{*}}{\mathrm{Pbc}}$} & \multirow[b]{2}{*}{$\begin{array}{l}\mathrm{Pbc} \\
(\mathrm{pg})\end{array}$} & \multirow[b]{2}{*}{$\frac{{ }^{206} \mathrm{~Pb}}{{ }^{204} \mathrm{~Pb}}$} & \multicolumn{7}{|c|}{ Radiogenic Isotopic Ratios } & \multirow[b]{2}{*}{$\begin{array}{l}\text { corr. } \\
\text { coef. }\end{array}$} & \multicolumn{6}{|c|}{ Radiogenic Isotopic Dates } \\
\hline & & & & & & & $\frac{{ }^{208} \mathrm{~Pb}}{{ }^{206} \mathrm{~Pb}}$ & $\frac{{ }^{207} \mathrm{~Pb}}{{ }^{206} \mathrm{~Pb}}$ & $\%$ err & $\frac{{ }^{207} \mathrm{~Pb}}{{ }^{235} \mathrm{U}}$ & $\%$ err & $\frac{{ }^{206} \mathrm{~Pb}}{{ }^{238} \mathrm{U}}$ & $\%$ err & & $\frac{{ }^{207} \mathrm{~Pb}}{{ }^{206} \mathrm{~Pb}}$ & \pm & $\frac{{ }^{207} \mathrm{~Pb}}{{ }^{235} \mathrm{U}}$ & \pm & $\frac{{ }^{206} \mathrm{~Pb}}{{ }^{238} \mathrm{U}}$ & \pm \\
\hline (a) & (b) & (c) & (c) & (c) & (c) & (d) & (e) & (e) & (f) & (e) & (f) & (e) & (f) & & (g) & (f) & (g) & (f) & (g) & (f) \\
\hline $\mathrm{z} 4$ & 0.519 & 0.5147 & $99.16 \%$ & 36 & 0.36 & 2149 & 0.164 & 0.052397 & 0.236 & 0.343260 & 0.279 & 0.047514 & 0.071 & 0.687 & 302.8 & 5.4 & 299.64 & 0.72 & 299.24 & 0.21 \\
\hline $\mathrm{z} 7$ & 0.278 & 0.4410 & $98.90 \%$ & 25 & 0.41 & 1640 & 0.088 & 0.052306 & 0.286 & 0.342322 & 0.329 & 0.047466 & 0.078 & 0.632 & 298.8 & 6.5 & 298.93 & 0.85 & 298.95 & 0.23 \\
\hline z3 & 0.329 & 0.5030 & $98.88 \%$ & 25 & 0.47 & 1604 & 0.104 & 0.052348 & 0.261 & 0.342587 & 0.306 & 0.047465 & 0.071 & 0.699 & 300.6 & 6.0 & 299.13 & 0.79 & 298.94 & 0.21 \\
\hline $\mathrm{z} 2$ & 0.161 & 0.3703 & $99.24 \%$ & 36 & 0.23 & 2381 & 0.051 & 0.052442 & 0.208 & 0.343195 & 0.255 & 0.047464 & 0.083 & 0.684 & 304.7 & 4.7 & 299.59 & 0.66 & 298.93 & 0.24 \\
\hline z1 & 0.215 & 0.5281 & $99.48 \%$ & 53 & 0.23 & 3457 & 0.068 & 0.052519 & 0.150 & 0.343667 & 0.199 & 0.047459 & 0.073 & 0.774 & 308.1 & 3.4 & 299.95 & 0.52 & 298.90 & 0.21 \\
\hline z6 & 0.253 & 0.6041 & $97.85 \%$ & 13 & 1.10 & 843 & 0.080 & 0.052308 & 0.278 & 0.342232 & 0.325 & 0.047452 & 0.074 & 0.707 & 298.9 & 6.3 & 298.86 & 0.84 & 298.86 & 0.22 \\
\hline $\mathrm{z} 8$ & 0.421 & 0.6489 & $99.22 \%$ & 37 & 0.43 & 2302 & 0.133 & 0.052192 & 0.232 & 0.341344 & 0.275 & 0.047433 & 0.071 & 0.684 & 293.8 & 5.3 & 298.19 & 0.71 & 298.75 & 0.21 \\
\hline $\mathrm{z} 5$ & 0.189 & 0.7163 & $98.89 \%$ & 25 & 0.67 & 1634 & 0.060 & 0.052408 & 0.221 & 0.341855 & 0.267 & 0.047309 & 0.073 & 0.715 & 303.3 & 5.0 & 298.58 & 0.69 & 297.98 & 0.21 \\
\hline
\end{tabular}

stones and fine-grained sandstones, possibly of fluvial in origin, dipping south-east $\left(120^{\circ} / 30^{\circ}\right)$. Because of vegetation cover the body is laterally traceable only for a few metres but scree fragments suggest its lateral extent further south for at least hundred metres. Gilíková in Buriánek et al. (2011) interpreted the stratigraphic position of the volcanic body within green-grey sediments in upper part of the Rosice-Oslavany Formation. To obtain more precise location we calculated vertical distance above the Coal I from data derived from the geological map and our field observations. Assuming the surface distance between outcrops of the Coal I and the volcanic bed at the $248 \mathrm{~m}$ a.s.l. is about $115 \mathrm{~m}$ and average dip of strata of $30^{\circ}$, the stratigraphic distance between the Coal I and the dated volcanite is $57 \mathrm{~m}$. This suggests the position of the volcanite less than $40 \mathrm{~m}$ above the Helmhacker Horizon. Although the volcanite has not been found in the well-studied Oslava River Section (Jaroš 1962, Pešek et al. 2001, Šimůnek \& Martínek 2009) located along the bank about $1 \mathrm{~km}$ further south (Fig. 7) its approximate position can be constrained from dip and strike of strata to below the top of the Rosice-Oslavany Formation (Fig. 9). 

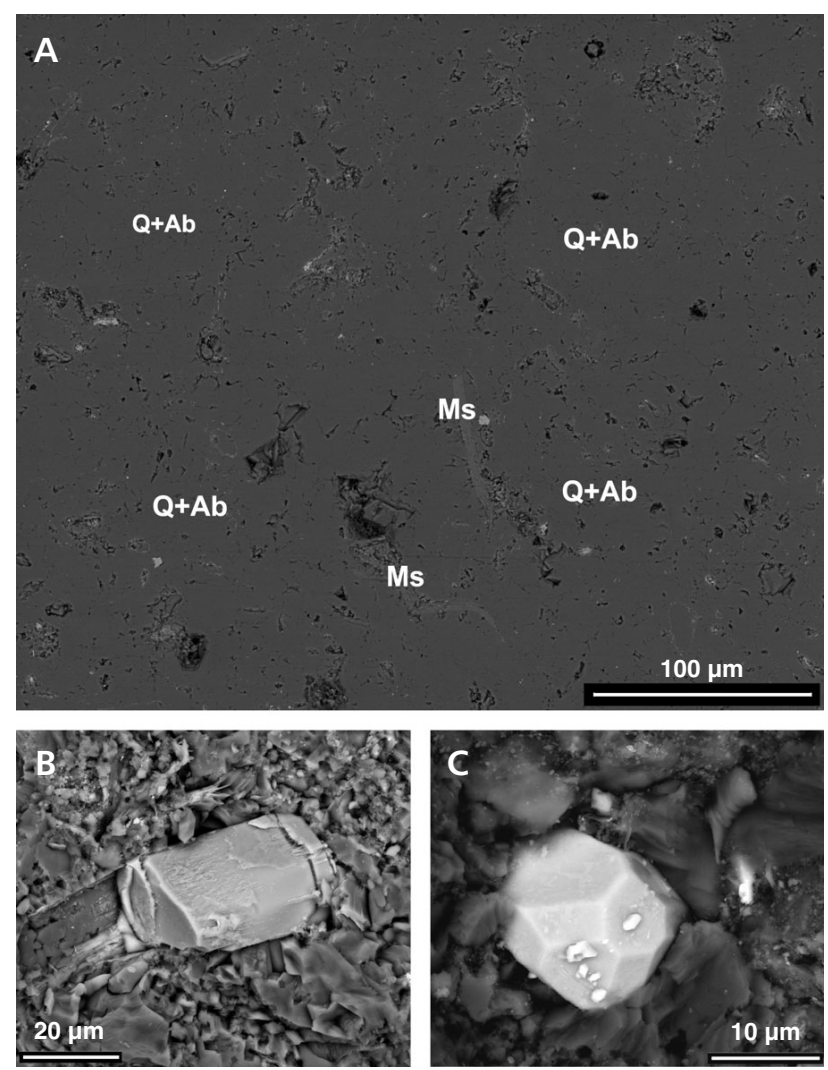

Figure 10. BSE images of dated volcanic rock. $\bullet A-$ polished thin section showing indistinguishable fine-grained matrix of quartz and albitized plagioclase $(\mathrm{Q}+\mathrm{Ab})$ with minor tables of muscovite $(\mathrm{Ms}) \cdot \bullet \mathrm{B}-$ broken prismatic apatite crystal. $\bullet \mathrm{C}$ - sharply faceted prismatic zircon.

\section{Petrography, mineralogy and chemical composition}

Macroscopically the dated volcanite is a green to grey fine-grained massive rock. In the basal part this greenish rock consists of volcanic ash with lapilli up to few centimetres in diameter. In the direct overburden of massive volcanic rock are tuffites with similar composition, i.e., albite prevailing over quartz, and mica mineral and mineral from the chlorite group. Microscopically the sample is a massive volcanic rock composed of very fine-grained matrix consisting solely of plagioclase and splinters of quartz. RTG data indicate albite as a dominant mineral (69\%), subdominant quartz (29\%), and subordinate muscovite $(1 \%)$ and hematite (1\%). SEM observations show presence of accessory crystals of zircon, apatite, baryte, and $\mathrm{TiO}_{2}$ minerals and possibly minerals of the monazite, xenotime, and rhabdophane groups (Fig. 10).

Chemical composition of the dated sample falls within a field of rhyolites $\left(\mathrm{SiO}_{2}=76.0 \mathrm{wt} \%\right.$ and $\mathrm{Na}_{2} \mathrm{O}+\mathrm{K}_{2} \mathrm{O}=$ $6.6 \mathrm{wt} \%$ ) in the TAS classification (Le Maitre 2002). The content of $\mathrm{K}_{2} \mathrm{O}(0.5 \mathrm{wt} \%)$ is very low whereas high concentration of $\mathrm{Na}$ suggests albitization of feldspar, which is seen also from spatial distribution of these elements done by element mapping. More details concerning mineralogy, petrology, and geochemistry of volcaniclastic complex are given in Jirásek et al. (unpublished data).

\section{Radioisotopic age of the volcanite}

The sample of the Oslavany volcanite (lower tuff part) contained a homogeneous population of prismatic zircon crystals with a variety of aspect ratios from near equant (1:1) to highly elongate (10:1). No rounded zircon crystals or other minerals suggestive of detrital input were recognized. From the most elongate prismatic crystals, eight crystals were selected for chemical abrasion, dissolution and isotope dilution analysis. Six of those eight crystals yielded concordant and equivalent $\mathrm{U}-\mathrm{Pb}$ isotope ratios, with a weighted mean ${ }^{206} \mathrm{~Pb} /{ }^{238} \mathrm{U}$ date of $298.88 \pm 0.09(0.17)[0.36] \mathrm{Ma}$ (MSWD $=0.52 ; n=6$ of 8 ). This date is interpreted as the age of rapid, immediately pre-eruptive zircon crystallization, and thus approximates the age of eruption and deposition of the tuff. Two additional crystals yielded slightly older or younger dates, which are interpreted as biased by crystal inheritance from earlier magmatic episodes or $\mathrm{Pb}$ loss, respectively.

\section{Biostratigraphy}

The rich fossil record of floras and faunas in the Boskovice Basin has resulted in establishment of independent biostratigraphies based on macrofloras, fish, amphibians and blattoid insects (e.g. Havlena 1964, Šimůnek in Pešek et al. 2001, Schneider \& Werneburg 2012, Zajíc 2000, Štamberg 2014). Unfortunately, there is no clear agreement among individual biostratigraphies and several contrasting opinions on chronostratigraphy exist. "Classical" is a floral biostratigraphy, formerly affected by the opinion that the first appearance of callipteris species indicates base of the Permian (e.g. Goeppert 1858, Geinitz 1865, Gothan 1912, Havlena 1964). This opinion was questioned by Němejc (1951) and later abandoned in agreement with findings of callipterids in the stratotype area of the Stephanian stage in French Massif Central and elsewhere in Europe (Bourouz \& Doubinger 1977, Kerp 1988, Broutin et al. 1990, Wagner \& Álvarez-Vázquez 2010), North America (DiMichele et al. 2013, DiMichele 2014) and north Africa (Hmich et al. 2006). Consequently Wagner \& Álvarez-Vázquez (2010) assigned their Autunia conferta zone to a Stephanian C-lower Autunian age, which is now considered to represent part of the Gzhelian (Gradstein et al. 2012; International Chronostratigraphic Chart v2016/v4). It should be mentioned that floral zonation, as suggested by these authors, is widely used in European basins, however, its two youngest zones, 
Figure 11. $\mathrm{U}-\mathrm{Pb}$ radioisotope results for Oslavany tuffite zircons, displayed in $\mathrm{U}-\mathrm{Pb}$ concordia space and as a ranked age plot.

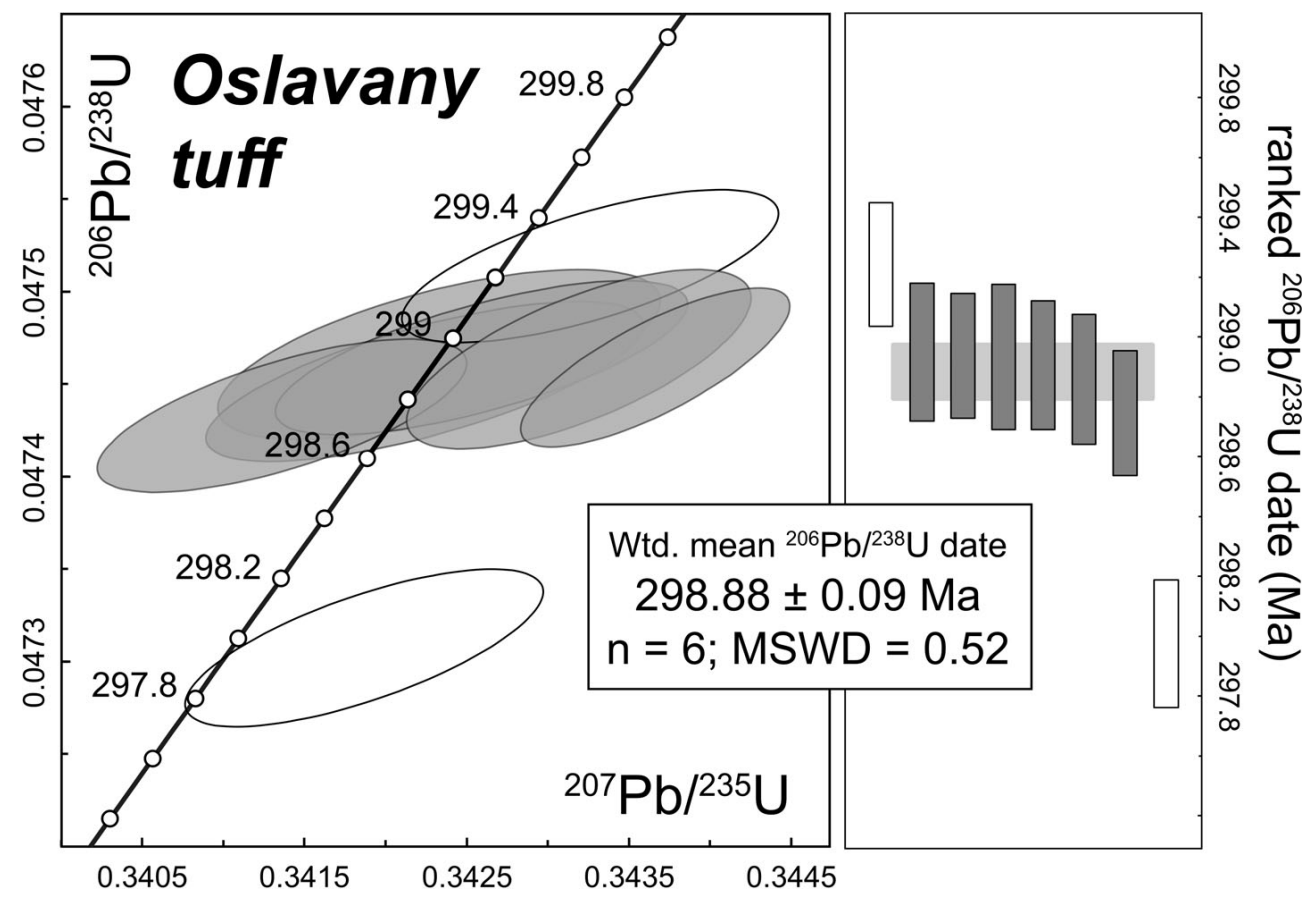

Autunia conferta and Annularia spicata, are rather poorly defined. Poor definition in comparison to older zones results from limited availability of fossiliferous successions, in which these biozones are completely preserved in context with the under/overlying ones and thus allowing much wider and reliable correlations among European basins. In addition, the fossil record across the CarboniferousPermian transition is concentrated mainly into discrete, usually lacustrine horizons (Opluštil et al. 2016b), and is thus less continuous compared to the Early to Middle Pennsylvanian coal-bearing strata. Except for Kozur's (1980) zonation based on the succession of callipteris flora, that has not been widely accepted (Kerp 1988), no other reliable macrofloral biozones exist above the youngest and poorly constrained Annularia spicata Zone of Wagner \& Álvarez-Vázquez (2010). For that reason, mostly faunas are used for the stratigraphic subdivision of Permian successions in the Boskovice and other basins elsewhere in Europe.

Macrofloral zones were first applied in the Boskovice Basin by Wagner (1984) and Šimůnek (in Pešek et al. 2001). They assigned the lower part of the RosiceOslavany Formation up to the level of the Coal II to the Sphenophyllum angustifolium Zone, whereas the interval between the Coal I and the Říčany Horizon in the upper part of the Padochov Formation was attributed to the Autunia conferta Zone (Fig. 5). The youngest Annularia spicata Zone was not defined yet in that time. The position of these zones in the Boskovice Basin is established on the presence of Sphenophyllum angustifolium in the coals II and III, the first occurrence of Neurocallipteris neuropteroides in the level of the Coal II, and of Autunia conferta, Ernestiodendron filiciforme and Walchia piniformis in the Coal I. Worth noting is Němejc's (1951) observation, that callipterids occur in close proximity to the Coal I, however, as drifted allochtonous remains together with walchian conifers in discrete beds separate from the hygrophyllous flora in the roof of the Coal I, dominated by typically late Stephanian species including Alethopteris zeilleri ( $=$ A. bohemica according to Němejc 1951). Slightly higher, in the Zbýšov Horizon, Annularia spicata occurs for the first time. Its first appearance marks the base of the middle to upper Autunian A. spicata Zone in western Europe (Wagner \& Álvarez-Vázquez 2010) and is thus in contradiction with the previous assignment of this interval to the $A$. conferta Zone by Šimůnek (in Pešek et al. 2001). This zone is characterised by increased diversity of peltasperms and conifers; however, its upper boundary is not clearly constrained because of generally poor fossil record due to low preservation potential.

Recently Opluštil et al. (2016a, b) provided high-precision radioisotopic ages and for the first time calibrated floral zones based on their ranges in the basins of central and western Bohemia and Sudetic area. There the upper boundary of the $S$. angustifolium Zone is estimated to be $\sim 300.5 \mathrm{Ma}$, whereas its position in the Boskovice Basin between the coals I and II (Šimůnek in Pešek et al. 2001) is probably slightly younger taking into account the new radioisotopic age $298.88 \pm 0.09$ Ma of the volcanic body above the Helmhacker Horizon.

This simple comparison suggests that top of the $S$. angustifolium or base of the A. conferta zones in the 
Boskovice Basin should be rather situated around the base of the Rosice-Oslavany group of coals (Fig. 5). The top of the $A$. conferta or base of the A. spicata Zone is rather poorly constrained in the basins of central and western Bohemia and the Sudetic basins (Opluštil et al. 2016a, b), but seems to be located approximately between 298.5 and 298.0 Ma. This interval is in the Boskovice basin situated most probably in the lower part of the Padochov Formation. Indeed, in the Zbýšov Horizon in lower part of the formation there is the first occurrence of A. spicata, thus marking the approximate position of base of the zone. Although Kozur's (1980) callipteris zones are not widely used, they can be constrained in the Boskovice Basin and demonstrate changes in callipteris flora throughout the section (Fig. 5).

The faunal record is concentrated into discrete lacustrine horizons and includes stratigraphically important amphibian, fish and blattoid insect species (Fig. 6). Amphibians and blattoid instect zonations are based on evolutionary lineages where disappearance of one key-taxon is replaced by another species of the same lineage (for details see Schneider \& Werneburg 2012). The chronostratigraphy of amphibians and insect zones is based on their correlation to marine biozones in basins where both terrestrial and marine sediments alternate, as well as on some radioisotopic dates by different methods of various precision (Schneider et al. 2014). These zonations, however, suggest different ages comparing to those based on fish faunas or floras. It is currently beyond the scope of existing data to resolve this disagreement. Instead, we explain our preferred chronostratigraphic interpretation based on fish fauna as suggested by Zajíc (2000) and Štamberg (2014). Sphaerolepis-Elonichthys, Acanthodes gracilis and Xenacanthus decheni zones have been identified in the Boskovice Basin as well as in the Krkonoše-Piedmont and Intra-Sudetic basins. Their identification is based on the occurrence of key-taxa (Fig. 6) and follows an assumption that since late Stephanian (Gzhelian) times all the continental basins in the Czech Republic were interconnected via river systems, which allowed exchange of fish faunas and thus make the correlation of lacustrine horizons among basins more reliable (Pešek et al. 1998, Opluštil et al. 2013, Štamberg 2014). Assuming the duration of each of these fish zones is $\sim 2-3$ Ma ( ̌́tamberg 2014), they together represent the interval from late Gzhelian to late Asselian. This conclusion is in agreement with the high-resolution $\mathrm{U}-\mathrm{Pb}$ isotopic ages of embedded volcanic rocks in the Intra-Sudetic and KrkonošePiedmont basins (Opluštil et al. 2016b). These volcanic rocks accompany the youngest fish-bearing lacustrine horizons (Kalná and Ruprechtice) assigned to the Xenacanthus decheni Zone and all three samples provided late Asselian ages between $296.49 \pm 0.08$ and $297.13 \pm 0.04$.

\section{Plant diversity and vegetation patterns}

About 94 whole-plant taxa have been identified so far in the Boskovice Basin (Fig. 5). Except for a few mostly poorly preserved gymnosperm remains found in the fluvial red beds, the entire plant fossil record is concentrated to usually grey to green-grey lacustrine strata and to the mudstones in the vicinity of coals, mostly in their roof (Augusta 1951, Němejc 1951, Šetlík 1951, Rieger 1965). These fossiliferous strata represent major windows of preservation and provide insight into the plant diversity of the basin landscape. Significant differences in stratigraphic ranges of individual taxa result in prominent changes in diversity as well as vegetation patterns throughout the fossiliferous part of the basin sequence (Figs 12,13). There is an initial rise in diversity, which doubles from base to top of the Rosice-Oslavany group of coals and reaches 54 species in the level of the Coal I. This significant diversification fully corresponds to increasing economic importance of individual coals and thus may partly reflex a sampling artefact at the lower edge of the taphonomic window. Above the Coal I diversity drops to 43 species in the Helmhacker Horizon and again rises to the maximum 55 species in the Zbýšov Horizon in the lower part of the Padochov Formation (Figs 5, 12, 13). The changes in diversity are accompanied by the disappearance of a suite of wetland species typical of the Rosice-Oslavany group of coals, and the onset of new taxa in the Zbýšov Horizon. A diversity level of $\sim 50$ species is typical for the entire Padochov Formation, above which there is a drop between the Ř́čany and Chudčice horizons from 50 to 39 species respectively. Diversity then becomes stable (38-41 species) throughout the $\sim 3000 \mathrm{~m}$ thick succession represented by the upper Veverská Bítýška and entire Letovice formations.

Vegetation patterns expressed either by numbers of species of major plant groups or by their percentage in the overall diversity in plant assemblage of individual fossiliferous intervals, vary significantly throughout the basin sequence. The most striking is a gradual shift from a gentle predominance in number of species of cryptogamic plants over the seed plants in the basal part of the basin succession to an opposite ratio in its upper part (Fig. 12). Expressed in numbers, about 20 cryptogamic species in the lower part of the basin succession are gradually reduced to 10 species in the top of the Letovice Formation, whereas about 10 seed plant taxa increase to 25-30 species in the opposite way. This trend is even more pronounced in the case of percentage of these two major plant groups due to a gradual decrease in overall diversity throughout the section. Thus the proportion of cryptogams decreases in two steps from $60 \%$ in the Coal III to only $25 \%$ in the Bačov Horizon at the top of the Letovice Formation (Fig. 12).

The decrease of cryptogamic plants is mainly due to the 


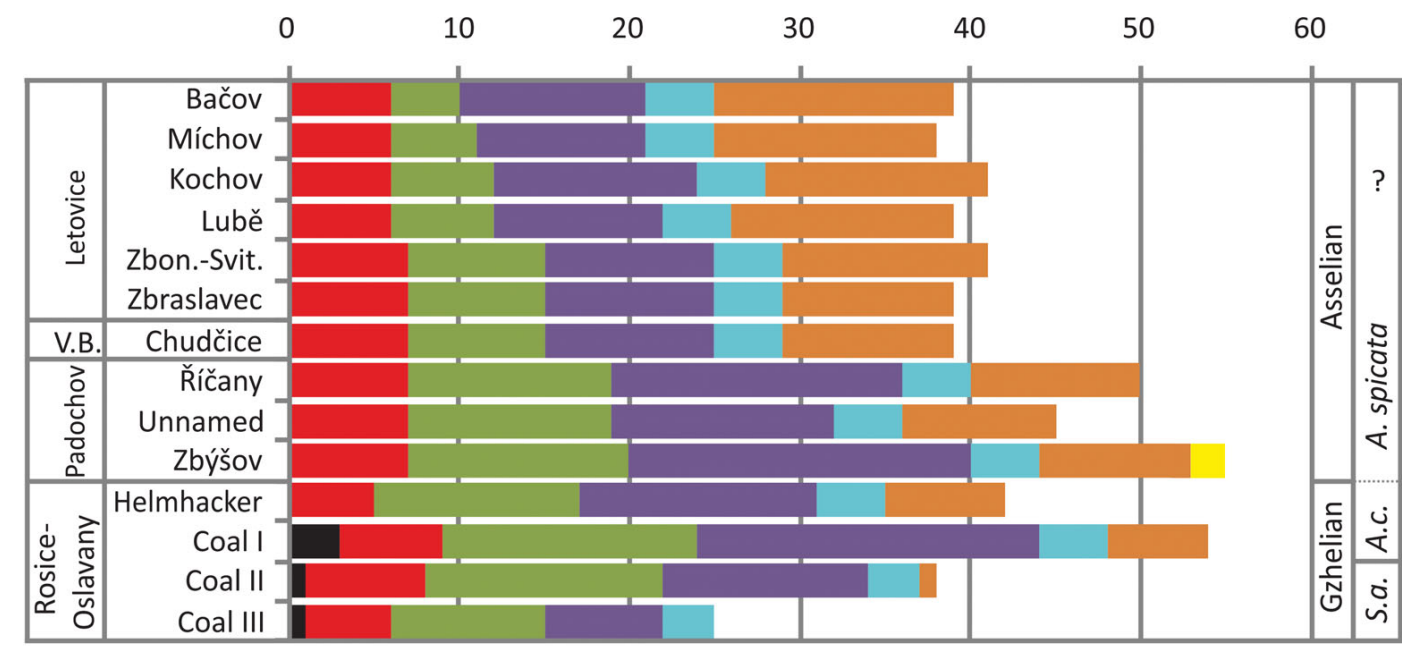

Overall diversity and number of species in major plant groups

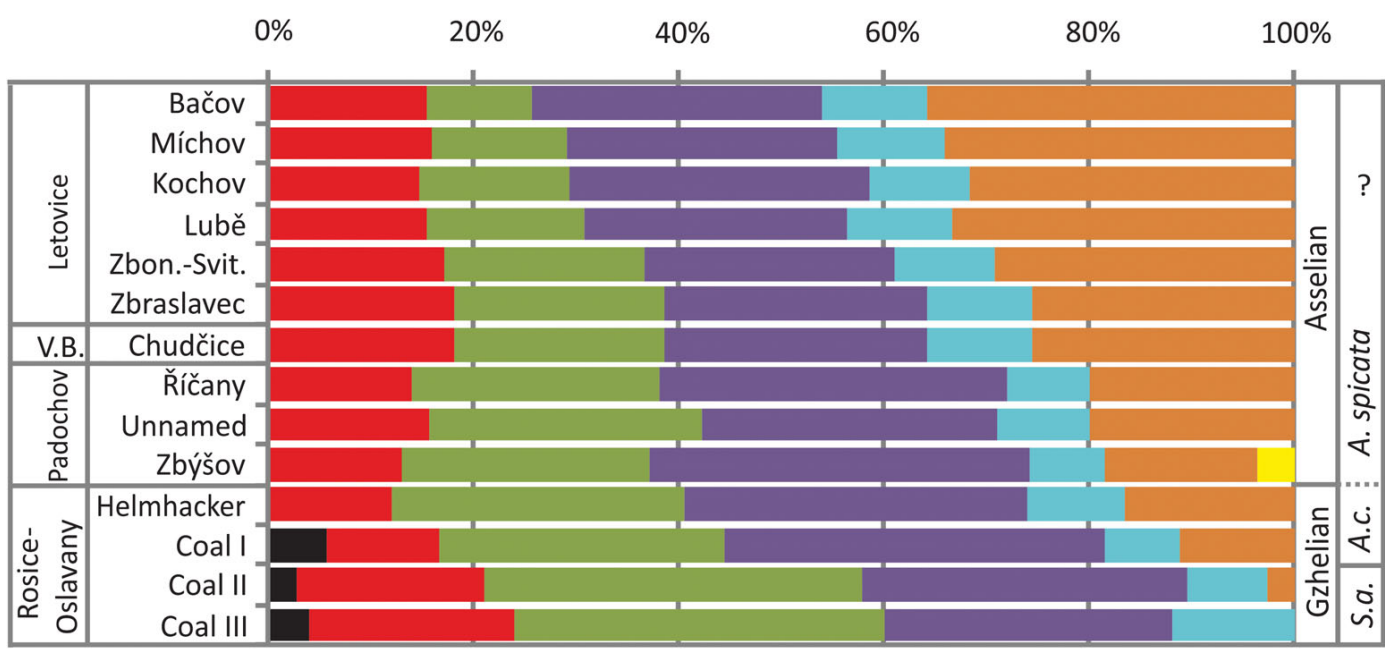

Normalised vegetation pattern (\%)

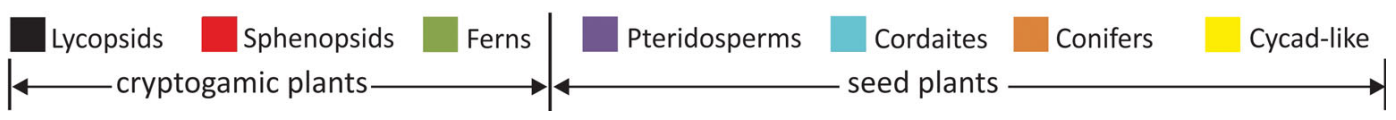

Figure 12. Vegetation patterns of individual fossiliferous horizons of the Boskovice Basin based on species diversity major plant groups. Abbreviations: V.B. - Veverská Bítýška, Zbon.-Svit. - Zboněk-Svitávka, S.a. - Sphenophyllum angustifolium, A.c. - Autunia conferta.

disappearance of ferns of all three major groups, zygopteridales, filicales and marattiales (Figs 12, 13), whereas sphenopsid diversity remains fairly unaltered. In the case of seed plants, an increase in number of species up the basin succession is observed among conifers. There are already 6 species just above the Coal I and this number increases to 13-14 species in the upper part of the Letovice Formation. This rise in the role of conifers in the fossil record is even more striking in normalised vegetation pattern (Fig. 12) where the percentage of conifers increases from a few to $\sim 35 \%$ at the top of the Letovice Formation.

A rather different pattern is displayed by pteridosperms (Figs 12, 13). They reach a maximum diversity of up to
20 species in the Padochov Formation from which their number decreases to $10-12$ in the remaining Veverská Bítýška and Letovice formations. Due to a more pronounced decrease in diversity of cryptogamic plants in the same way, however, the percentage of pteridosperms throughout the basin sequence remains nearly constant. Apparent trends exist among particular plant groups within pteridosperms. Concerning species numbers, medullosaleans reach the maximum diversity in the Rosice-Oslavany group of coals $(\leq 11)$, whereas maximum diversity of peltasperms, up to 9 species, is achieved in the overlying Padochov Formation of early Asselian age (Fig. 13). Plants of uncertain affinity, possibly pteridosperms (Taylor et al. 
2009) including genera Taeniopteris and Supaia appear at a maximum of 4 species in the upper part of the Letovice Formation, whereas only one species is present in the late Gzhelian Rosice-Oslavany Formation. Their increasing role to top of the basin succession (late Asselian) is amplified when expressed as percentage of overall diversity (Fig. 13).

\section{Similarity of plant assemblages}

Plant assemblages of major fossiliferous horizons were statistically evaluated by calculating measure of similarity for the constrained unweighted pairs using the Simpson coefficient (Fig. 14). For each horizon we included species that have been physically found in the particular horizon as well as those whose presence is assumed from their occurrence below and above. Three stratigraphically constrained major clusters represent principal plant assemblages established after major compositional and ecological changes, possibly driven by climate. In other words, each of major clusters represents intervals of relative ecological and compositional stability with only minor changes in plant assemblages between neighbouring lacustrine horizons.

The cluster 1 is characterised by dominance of hygrophilous flora of clastic and peat-forming wetlands that includes sigillarians and even lepidodendroid lycopsids, although dominating are maratiallean ferns. Subdivision into two subgroups is due to occasional appearance of conifer and peltasperm remains, typical of the Permian part of the succession, in the vicinity of the Coal I and in the Helmhacker Horizon above it. These are, however, found as drifted allochtonous remains separate from typical hygrophilous flora (Němejc 1951). The cluster 2 includes lacustrine horizons of the Padochov, Veverská Bítýška and lower parts of the Letovice formations, up to the level of the Zboněk-Svitávka Horizon. According to Šimůnek \& Martínek (2009) assemblages of these fossiliferous horizons are dominated by pteridosperms with conifers being co-dominant or subdominant. The cluster 3 groups horizons in the upper part of the Letovice Formation, the plant assemblages of which are dominated by conifers, as reflected in their diversity (Figs 12,13) as well as in predominance of their remains (Šimůnek \& Martínek 2009). Worth noting is that these major clusters of similarity of plant assemblages nearly faithfully correspond to the assemblages of fish faunas as suggested by Zajíc (2000) and Štamberg (2014).

\section{Discussion}

The Late Pennsylvanian-Early Permian is a time of the Late Paleozoic Ice Age culmination (see Fielding et al.
2008, Bishop et al. 2009, Isbell et al. 2012, Montañez \& Poulsen 2013). Physical environmental data from this interval provide support for a long-term, $10^{7}$-year scale progressive trend of warming and increasing drying in equatorial Pangea (Schneider et al. 2006, Montañez et al. 2007, Tabor \& Poulsen 2008). Combined with this trend are shorter $10^{6}$-year scale intervals of global warming and cooling (Birgenheier et al. 2009), recorded in the paleotropics of central and western Pangea as alternation of dry and wet phases (Roscher \& Schneider 2006, Opluštil \& Cleal 2007), and possibly related to incompletely understood variations in $\mathrm{CO}_{2} / \mathrm{O}_{2}$ levels in the atmosphere (Horton et al. 2007), although there is a parallel opinion that substrate dryness, driven at least partly by tectonic processes, may be a more important controlling factor than simple climate (Cleal et al. 2010, 2011).

Further superimposed on these intervals are even shorter climatic oscillations of $\sim 10^{5}$ years recorded as glacio-eustatically driven cycles or cyclothems (Tandon \& Gibling 1994, Gibling \& Rygel 2008, Heckel 2008). This climatic complexity is evident not only from the sedimentary record and paleosols (Driese \& Ober 2005; Tabor et al. 2008; Rosenau et al. 2013a, b; Allen et al. 2014; Opluštil et al. 2015; Lojka et al. 2009, 2016), but also from time-coinciding changes of terrestrial biota (e.g. Falcon-Lang et al. 2009, 2011; DiMichele et al. 2006, 2008; DiMichele 2014).

In the Boskovice Basin the overall trend of increasing aridity and drying is recorded as a transition from the upper Gzhelian grey coal-bearing strata of the Rosice-Oslavany Formation to the lower Cisuralian dominantly red bed strata of the Padochov, Veverská Bítýška and Letovice formations. This climatic trend affected also the preservation of organic matter and character of plant fossil-bearing horizons. In the Rosice-Oslavany Formation these were mostly peat and clastic swamps developed on lake shallows (ك̌imůnek \& Martínek 2009). Lake level prevented the wetlands from seasonal water table changes and allowed long-lasting peat accretion. In contrast from the overlying Padochov Formation, coal seams, even thin, are absent. Instead, plant remains are preserved only in nearshore mudstones and siltstones or offshore black shales and organic matter-rich limestones, whereas dessication cracks are observed in lake mudflat sediments of the Chudčice Horizon (Šimůnek \& Martínek 2009).

The presence of a few to tens of metres thick grey, mostly lacustrine intervals "interrupting" the overall fluvial red beds succession (Nehyba \& Mastalerz 1997, Pešek et al. 2001) suggests the existence of shorter-term climatic oscillations between semi-humid to semi-arid conditions (Šimůnek \& Martínek 2009). Similar climatic oscillations may have resulted in alternation of peat and clastic deposition of the Rosice-Oslavany group of coals, the latter being 


\section{Sphenopsids}
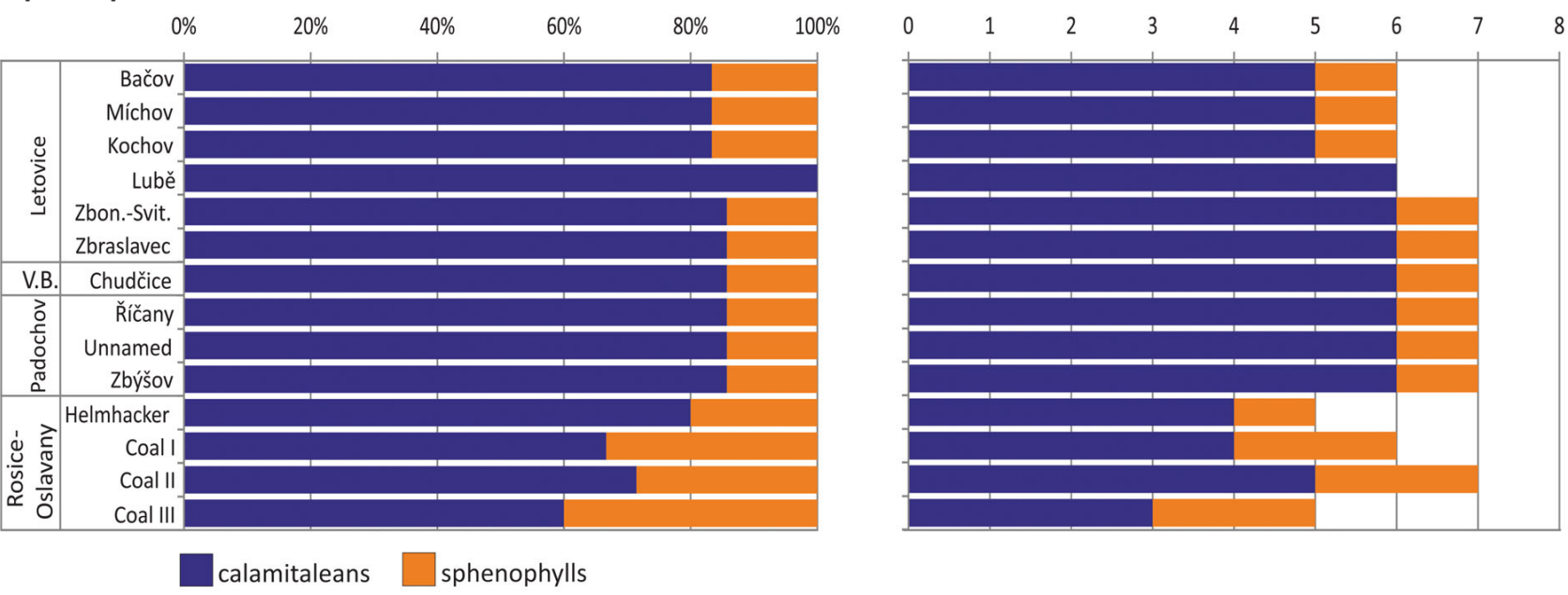

\section{Ferns}
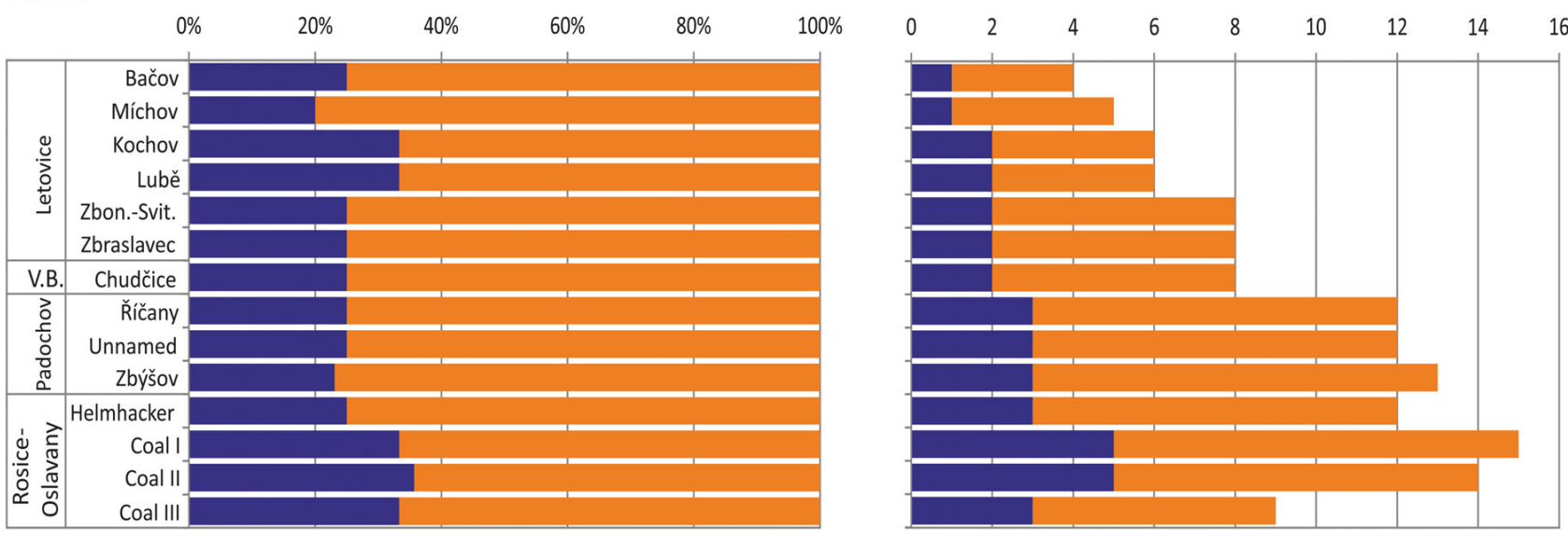

Zygopteridales + Filicales $\square$ Marattiales

\section{Pteridosperms}

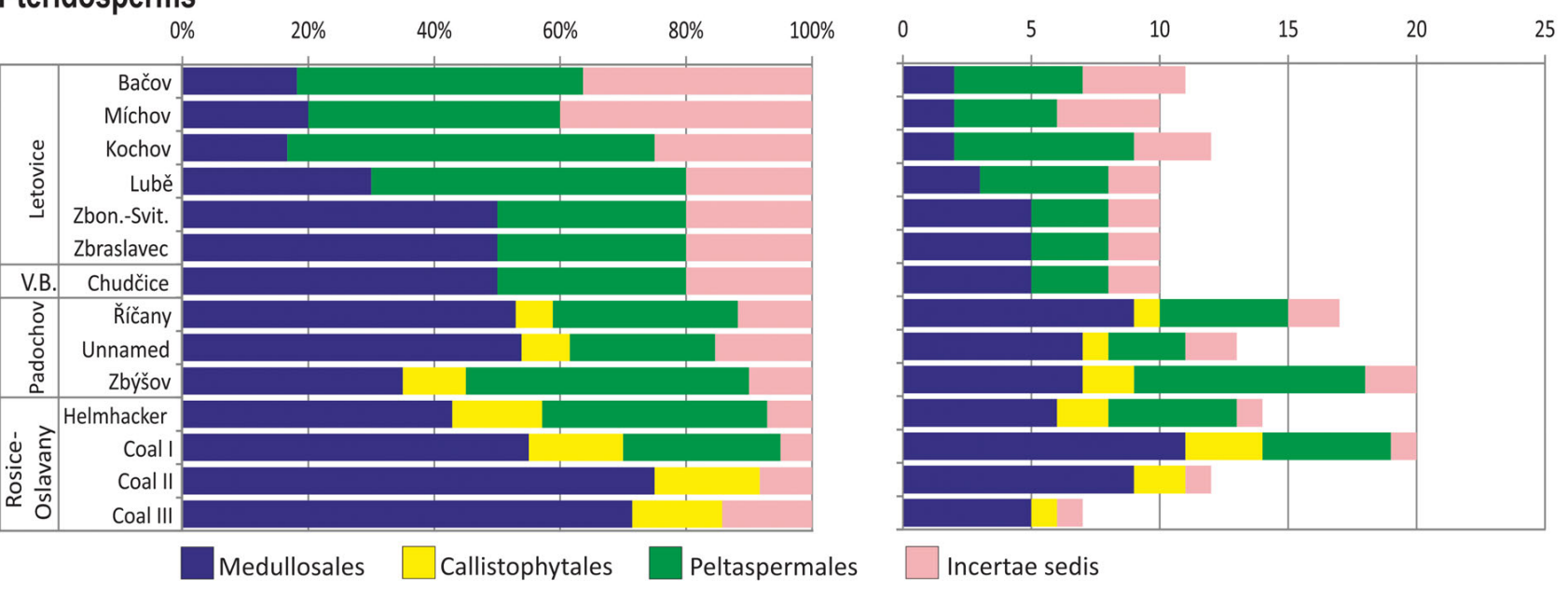

Figure 13. Vegetation patterns within major plant groups. Abbreviations: V.B. - Veverská Bítýška, Zbon.-Svit. - Zboněk-Svitávka. 


\begin{tabular}{|c|c|c|c|c|c|c|c|}
\hline \multicolumn{8}{|c|}{ Similarity } \\
\hline 응 & 穴 & 잉 & जे & 응 & $\stackrel{\circ}{\circ}$ & 응 & 융 \\
\hline
\end{tabular}

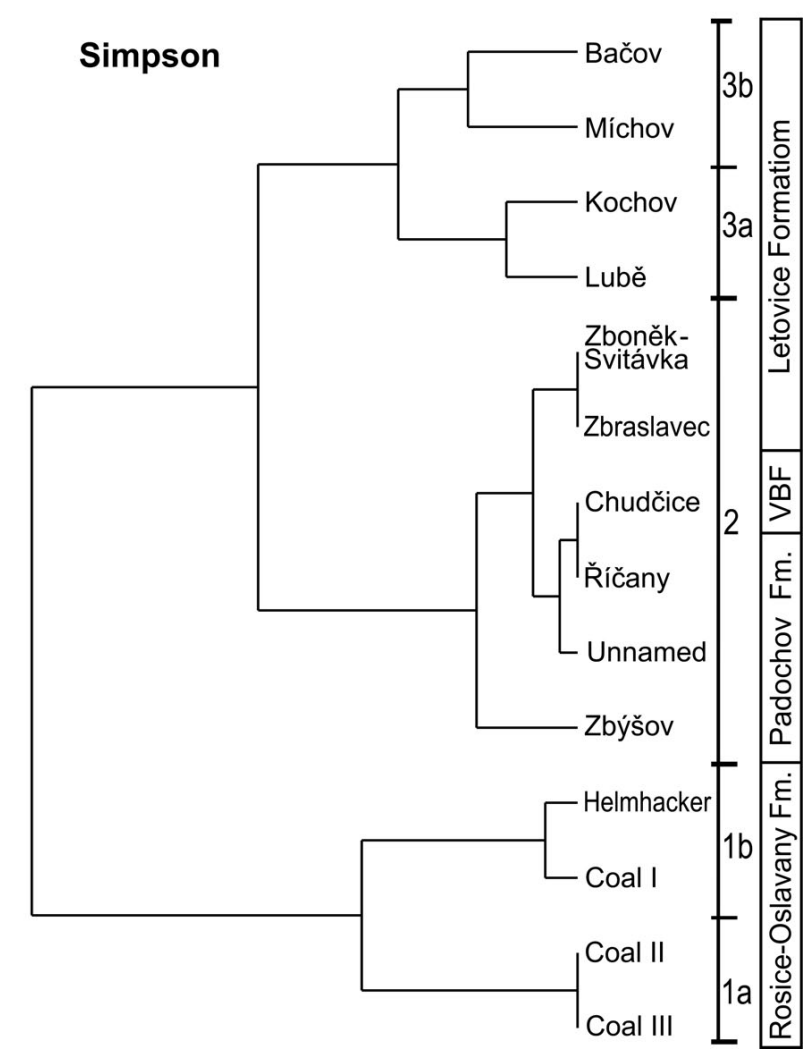

Figure 14. Dendrogram of macrofloral assemblages of the Boskovice Basin following constrained cluster analysis of unweighted pairs using Simpson coefficient. The principal clusters reflect major changes in macroflora and are discussed in the text. Abbreviations: VBF - Veverská Bíty̌ška Formation.

locally red. Assuming the coal-bearing cycles of these continental basins were driven by similar mechanisms to cyclothems of the paralic basins (glacieustacy driven by global climate), their length can be estimated in rank of ky (Heckel 2008, Gastaldo et al. 2009).

The rich fossil record analysed in this study comes from windows of preservation formed under high and stable ground-water table (late Gzhelian) or lake level (Asselian), both maintained by relatively humid climate. In contrast the fossil record of drier intervals represented by red beds is insufficiently known due to low preservation potential resulting in rareness of plant fossils and their poor quality. These are mostly conifer impressions.

Plant assemblages from humid intervals (grey horizons) differ temporally based on the frequency of their findings (Šimůnek \& Martínek 2009). Coal seams of the Rosice-Oslavany group, especially their roof shales are dominated by hygrophilous tree fern (Šimůnek \& Martínek 2009). Locally codominant are sphenopsids whereas pteridosperms, mostly medulosalleans (e.g. Alethopteris zeilleri, Odontopteris schlotheimi) or callistophytaleans (Dicksonites pluckenetii) are subdominant to rare. Typical, although rare, are remains of arborescent lycospids, Sigillaria brardii, Lepidophloios cf. acerosus and Lepidodendron sp., the latter two typical of Westphalian peat swamps (DiMichele \& Phillips 1994, DiMichele et al. 2010). In contrast, the hygrophilous assemblage from the roof of coals lacks the remains of callipterids and conifers. Callipterids appear for the first time in a close proximity above the roof of the Coal I, but separately from the hygrophilous flora (Augusta 1946, Němejc 1951). Their fragments occur in association with similarly fragmented conifer remains and unidentifiable plant detritus thus indicating an allochtonous origin of the assemblage (Němejc 1951). The onset of callipterids above the Coal I possibly indicates a climatic shift to drier conditions (Šimůnek \& Martínek 2009). Floras of lacustrine horizons of the Padochov Formation are generally mixed pteridospermand conifer-dominated assemblages as indicated both by diversity patterns (Figs 12,13) and frequency of their plant remains (Šimůnek \& Martínek 2009). In contrast, the Chudčice Horizon in the Veverská Bítýška Formation provided plant assemblages dominated by conifers (Šimůnek \& Martínek 2009) and a marked drop of diversity of ferns and pteridosperms including peltasperms (Figs 12, 13). Conifers are considered as one of the most reliable indicators of environments with seasonal moisture stress (DiMichele 2014) and their dominancy in this level indicates further shift to drier climate. A return to pteridosperm-dominated flora is observed in the ZboněkSvitávka and Lubě lacustrine horizons in the lower part of the Letovice Formation (Šimůnek \& Martínek 2009). The pteridosperms are dominated by peltasperms, especially by Autunia conferta, and this assemblage possibly indicates a slight increase of humidity. Flora of the Míchov and Bačov lacustrine horizons in the upper part of the Letovice Formation are again conifer-dominated based on frequency of their remains, and therefore interpreted as evidence for increased aridity in comparison with the lower part of the Letovice Formation (Šimůnek \& Martínek 2009). This interpretation is in agreement with diversity of plant assemblages of this stratigraphic interval (Figs 12, 13), where conifers attain the highest diversity of all plant-bearing intervals of the Boskovice Basin. In contrast diversity of ferns significantly decreases. Typical for these youngest lacustrine windows are representatives of the genera Taeniopteris and Supaia. The above described assemblages clearly indicate a gradual, although not regular trend of increasing aridity recorded as a transition from the hygrophilous plant assemblage of the Rosice-Oslavany group of coals to peltasperm and especially conifers dominated plant assemblages preserved in the lacustrine horizons of Permian part of the basin succession. 


\section{Comparisons}

The above-described succession of vegetation patterns and plant assemblages around the Carboniferous-Permian transition is not unique to the Boskovice Basin but has been observed elsewhere in Europe and North America where this transition is preserved (Broutin et al. 1990, 1992; Châteauneuf et al. 1992; DiMichele et al. 2001, 2005, 2007; Barthel \& Rößler 2012, Opluštil et al. 2016b). This trend is characterised by a general decline of "Carboniferous-type" wetlands flora and increasing importance of walchian conifer-peltasperm floras (Kerp 1996, 2000; DiMichele et al. 2005, 2008, 2009; DiMichele 2014; Looy et al. 2014). The latter appear sporadically in the basin lowlands during the Late Pennsylvanian and become dominant during the early Permian as a consequence of aridification trend (DiMichele et al. 2008). Spatio-temporal differences in vegetation patterns and their successions, however, exist across central and western tropical Pangea, including the local presence of some "Mesophytic" elements like taeniopterids, supaioids and Podozamites or voltzian conifers (DiMichele et al. 2001). Some of these assemblages have been found in association with evaporites or calcic vertisols suggesting strong seasonality further supported by presence of growth rings (Falcon-Lang et al. 2011, 2014). Detailed comparison is, however, beyond the scope of this study, partly because of absence of precise radioisotopic data to establish high-resolution correlation between individual areas. Currently only the Intra-Sudetic Basin in the northern part of the Czech Republic provides the comparably high stratigraphic resolution and data for comparison (Opluštil et al. 2016b). In the Intra-Sudetic Basin the radioisotopically constrained Carboniferous-Permian transition is recorded in the Chvaleč and Broumov formations, the floras and fish faunas of which are equivalent to the entire Boskovice Basin succession. The apparent difference between these two areas exists in overall floral diversity, which is more than doubled in the Boskovice Basin (up to $\sim 50$ species comparing to over 20 species maximum in this interval in the Intra-Sudetic Basin). Apart from this difference the vegetation patterns are very similar, showing an increase in diversity of conifers and peltasperms throughout this interval and decrease of "Carboniferous-type" wetlands flora or complete decline of some of its elements (lepidodenroid lycopsids). In the Intra-Sudetic Basin the percentage of conifers in vegetation patterns increases from $12 \%$ in the late Gzhelian to about 40-50\% in the late Asselian part of the succession. In equivalent strata of the Boskovice Basin the proportion of conifers rises from few to $\sim 35 \%$ (Fig. 12). Differences of similar rank exist also among most other groups; however, increasing proportion of conifers and peltasperms up the section is obvious in both basins for time equivalent strata.

\section{Summary and conclusions}

The Boskovice Basin is a half-graben that preserves about $5 \mathrm{~km}$ thick succession of continental red beds interrupted by grey mostly lacustrine horizons bearing rich floras and faunas, and recording biotic changes across the Carboniferous-Permian transition. Our new high-resolution U-Pb CA-IDTIMS dating of single zircon crystals separated from acid volcanic rock embedded below the top of the Rosice-Oslavany Formation in lower part of the basin succession provided an age of $298.88 \pm 0.09 \mathrm{Ma}$. This age nearly exactly corresponds to the Carboniferous-Permian boundary as currently accepted by the International Chronostratigraphic Chart (v2016/4). Physical connection of the Boskovice Basin with the Intra-Sudetic and Krkonoše-Piedmont basins in northern part of the Czech Republic allowed for correlation of their successions based on similarities of their fish faunas. This correlation suggests a late Asselian age for the youngest fish faunas of the Boskovice Basin. This age is confirmed also by radioisotopic ages of volcanites embedded in strata associated with lacustrine horizons bearing very similar fish faunas in the Intra-Sudetic and Krkonoše-Piedmont basins. These radioisotopic ages enable us to better characterise vegetation changes in purely continental settings in a temporal context and to correlate them with global marine stages.

The fill of the Boskovice Basin records a well-known aridification trend marked by the transition from Late Gzhelian grey coal-bearing strata to Asselian fluvial red beds. The red beds succession is interrupted by grey lacustrine horizons suggesting that upon the long-term trend of increasing aridity are superimposed shorter-term oscillations between drier and more humid climates. Possible existence of even shorter climatic variations is indicated by lake level fluctuation and occasional complete dessication.

These climatic changes had a profound effect on biota and affected its preservation. Fossil remains are concentrated into windows of preservation formed under high ground water table or lake level during humid phases. Vegetation patterns of individual windows of preservation, formerly being wetlands and lakes, mimic the major climatic variations. In the broadest view they clearly demonstrate the overall aridification trend between late Gzhelian and late Asselian times. It is characterised by transition from assemblages dominated by free-sporing plants, mostly tree ferns, typical of Late Pennsylvanian wetlands, to peltasperm-walchian conifers-dominating patterns. Similar successions have been observed elsewhere in the former central and western equatorial Pangea including the Intra-Sudetic Basin. Vegetation patterns of equivalent strata of both basins shows strong similarity, although diversity in the Intra-Sudetic basin is only about half of that in the Boskovice Basin. 


\section{Acknowledgement}

The authors of this contribution greatly acknowledge the financial support of the Grant Agency of the Czech Republic via the grant project P210-12-2053. Part of the research was also supported from the internal project Prvouk 44 of the Faculty of Science, Charles University. This paper is also a contribution to the aims of the Non-Marine-Marine Late Carboniferous-Permian-Early Triassic Working Group of the respective International Subcommissions on Stratigraphy of the IUGS. The authors greatly acknowledge the recommendations suggested by the both reviewers, J. Schneider (Freiberg, Germany) and one anonymous reviewer that significantly improved the quality of this article. The authors also would like to thank S. Stamberg (Hradec Králové, Czech Republic) for a valuable discussion on stratigraphic ranges of vertebrate faunas in the Boskovice Basin.

\section{References}

Allen, J.P., Fielding, C.R., Gibling, M.R. \& Rygel, M.C. 2014. Recognizing products of palaeoclimate fluctuation in the fluvial stratigraphic record: An example from the Pennsylvanian to Lower Permian of Cape Breton Island, Nova Scotia. Sedimentology 61(5), 1332-1381. DOI 10.1111/sed.12102

Augusta, J. 1926. Fauna v permu boskovické brázdy. Věstník klubu př́rodovědeckého v Prostějově za rok 1922-25 19, 25-40.

Augusta, J. 1927. Př́ispěvek k fytopaleontologii moravského permokarbonu. Časopis Vlasteneckého musejního spolku v Olomouci 39, 15-26.

Augusta, J. 1928. Callipteris Purkyněi sp. n. z discosaurového horizontu ve spodním permu boskovické brázdy a zpráva o nových palaeontologických nálezech $\mathrm{v}$ témž horizontu u kóty 383 (sz. od Boskovic). Věstník Státního geologického ústavu Československé republiky 4, 30-37.

Augusta, J. 1929. Př́spěvek k fytopalaeontologii palaeoniscového horizontu ve spodním permu boskovické brázdy. Věstník Státního geologického ústavu Československé republiky 5, 172-177.

AuguSTA, J. 1931a. Flora z permu a karbonu boskovické brázdy na Moravě. Časopis Vlasteneckého musejního spolku v Olomouci 44, 243-261.

Augusta, J. 1931b. Nová palaeontologická lokalita ve spodním permu střední části boskovické brázdy na Moravě. Časopis Vlasteneckého musejního spolku v Olomouci 44, 284-285.

Augusta, J. 1931c. O fosilních rybách v permu boskovické brázdy. Od Horácka k Poddyjí 8, 357-363.

Augusta, J. 1933a. Z dějin geologického a palaeontologického bádání v permokarbonu boskovické brázdy. Věstník klubu přirodovědeckého v Prostějově 23, 15-51.

Augusta, J. 1933b. O vyhynulých krytolebcích (Stegocephalech) a jejich zástupcích ve spodním permu moravském. Příroda 26(5), 120-128.

Augusta, J. 1934. Konifery moravského permokarbonu. Př́roda $27,18-21$.

Augusta, J. 1935. O novém paleontologickém sběru z permu okolí boskovického. Časopis Vlasteneckého musejního spolku v Olomouci 48, 146-147.

Augusta, J. 1937a. Z dějin stratigrafického výzkumu permokarbonu kamenouhelné pánve rosicko-oslavanské. Hornický věstník a hornické a hutnické listy 1937, 1-15, 23-24.

Augusta, J. 1937b. Über die Arten der Gattung Callipteris Bgt. aus dem Oberkarbon des Steinkohlenbeckens von Rosice und Oslavany in Mähren (Tschechoslowakei). Zentralblatt für Mineralogie, Teil II, 223-229.

Augusta, J. 1946. Poznámky k paleontologickému nalezišti pod „Konvízem“ v údolí Neslovického potoka mezi Neslovicemi a Padochovem na Moravě. Př́roda 38, 51-52.

Augusta, J. 1949. Dnešní stav znalostí o květeně spodního permu v okolí Černé Hory, Boskovic a Letovic. Časopis Vlasteneckého musejního spolku v Olomouci 58, 1-20.

Augusta, J. 1951. Spodnopermská květena kamenouhelné pánve rosicko-oslavanské a jejího širšího okolí. Sborník Ústředního ústavu geologického, Oddíl paleontologický 18, 397-424.

BARThel, M. \& RößLeR, R. 2012. Pflanzen und Pflanzengesellschaften des Rotliegend, 79-97. In LÜTZNER, H. \& Kowalczyк, G. (eds) Stratigraphie von Deutschland X: Rotliegend Teil I: Innervariscische Becken. Schriftenreihe der Deutschen Gesellschaft für Geowissenschaften 61.

BEYRICH, H.E. 1844. Über die Entwicklung des Flötzgebirges in Schlesien. B. Karsten's Archiv für Mineralogie, Geognosie, Bergbau und Hütte 18, 3-86.

Birgenheier, L.P., Fielding, C.R., Rygel, M.C., Frank, T.D. \& ROBERTS, J. 2009. Evidence for dynamic climate change on sub-106-year scales from the late Paleozoic glacial record, Tamworth Belt, New South Wales, Australia. Journal of Sedimentary Research 79, 56-82. DOI 10.2110/jsr.2009.013

Bishop, J.W., Montañez, I.P., Gulbranson, E.L. \& Brenckle, P.L. 2009. The onset of mid-Carboniferous glacioeustasy: sedimentologic and diagenetic constraints, Arrow Canyon, NV. Palaeogeography Palaeoclimatology Palaeoecology 276, 217-243. DOI j.palaeo.2009.02.019

Bourouz, A. \& Doubinger, J. 1977. Report on the Stephanian-Autunian Boundary and on the contents of upper Stephanian and Autunian in their stratotypes, 147-169. In Holub, V.M. \& Wagner, R.H. (eds) Symposium on Carboniferous Stratigraphy. Ústřední ústav geologický, Praha.

Broutin, J., Châteauneuf, J.J. \& Mathis, V. 1992. Permian Basins in the French Massif Central, Chapter I: The Lodève Basin. Cahiers de Micropaléontologie 7(1-2), 107-122.

Broutin, J., Doubinger, J., Farjanel, G., Freytet, P. \& Kerp, H., Langiaux, J., Lebreton, M.I., Sebban, S. \& Satta, S. 1990. Le renouvellement des flores au passage Carbonifère Permien: approche stratigraphique, biologique, sédimentologique. Compte Rendu de l'Académie des sciences, Paris 321, $1563-1569$.

Broutin, J., Doubinger, J., Langiaux, J. \& Primey, D. 1986. Conséquences de la coexistence de flores à caractères stéphaniens et autunians dans les bassins limniques d'Europe occidentale. Mémoires de la Société Géologique de France $149,15-25$.

Buriánek, D., Bubík, M., Francư, J., Fürychová, P., Havlín, A., Gilíková, H., Janderková, J., KoneČnÝ, F., KrejČí, Z., 
Krumlová, H., Kryštofová, E., Kunceová, E., Müller, P., Otava, J., Paleček, M., Pecina, V., Poul, I., Sedláček, J., SkÁcelová, Z., Šrámek, J., Petrová, P., Verner, K., VeČeřa, J. \& VíT, J. 2011. Vysvětlivky k základní geologické mapě České republiky 1: 25000 list 24-341 Oslavany. MS Závěrečná zpráva, Česká geologická služba, Praha.

CECIL, C.B. 1990. Paleoclimate controls on stratigraphic repetition of chemical and siliciclastic rocks. Geology 18, 533-536. DOI 10.1130/0091-7613(1990)018<0533:PCOSRO>2.3.CO;2

Cecil, C.B., DiMichele, W.A. \& Elrick, S.D. 2014. Middle and Late Pennsylvanian cyclothems, American Midcontinent: Ice-age environmental changes and terrestrial biotic dynamics. Comptes Rendus Geoscience 346, 159-168. DOI 10.1016/j.crte.2014.03.008

Châteauneuf, J.J., Farjanel, G., Pacaud, G. \& Broutin, J. 1992. Permian Basins in the French Massif Central, Chapter II: The Autun Permian Basin, the Autunian stratotype. Cahiers de Micropaléontologie 7(1-2), 107-121.

Cleal, C.J. 2005. The Westphalian macrofloral record from the cratonic central Pennines Basin, UK. Zeitschrift der Deutschen Gesellschaft für Geowissenschaften 156, 387-410. DOI 10.1127/1860-1804/2005/0156-0387

Cleal, C.J., Opluštil, S., Thomas, B.A. \& Tenchov, Y. 2010. Late Moscovian terrestrial biotas and palaeoenvironments of Variscan Euramerica. Netherlands Journal of Geosciences 88, 181-278. DOI 10.1017/S0016774600000846

Cleal, C.J., Opluštil, S., Thomas, B.A. \& Tenchov, Y. 2011. Pennsylvanian vegetation and climate in tropical Variscan Euramerica. Episodes 34, 3-12.

Cleal, C.J., Uhl, D., Cascales-Miñana, B., Thomas, B.A., Bashforth, A.R., King, S.C. \& Zodrow, E.L. 2012. Plant biodiversity changes in Carboniferous tropical wetlands. Earth Science Reviews 114, 124-155. DOI 10.1016/j.earscirev.2012.05.004

Condon, D., Schoene, B., Bowring, S., Parrish, R., McLean, N., Noble, S. \& Crowley, Q. 2007. EARTHTIME; isotopic tracers and optimized solutions for high-precision U-Pb ID-TIMS geochronology. Eos, Transactions, American Geophysical Union 88, Fall Meeting Supplement, Abstract V41E-06.

Davydov, V.I., Crowley, J.L., Schmitz, M.D. \& Poletaev, V.I. 2010. High-precision U-Pb zircon age calibration of the global Carboniferous time scale and Milankovitch band cyclicity in the Donets Basin, eastern Ukraine. Geochemistry, Geophysics, Geosystems 11(1), 1-22. DOI 10.1029/2009gc002736

DiMichele, W.A. 2014. Wetland-Dryland Vegetational Dynamics in the Pennsylvanian Ice Age Tropics. International Journal of Plant Sciences 175(2), 123-164. DOI 10.1086/675235

DiMichele, W.A. \& Aronson, R.B. 1992. The Pennsylvanian-Permian vegetational transition: a terrestrial analogue to the onshore-offshore hypothesis. Evolution 46, 807-824. DOI 10.2307/2409648

DiMichele, W.A. \& Phillips, T.L. 1994. Paleobotanical and paleoecological constraints on models of peat formation in the Late Carboniferous of Euramerica. Palaeogeography Palaeoclimatology Palaeoecology 106, 39-90.

DOI 10.1016/0031-0182(94)90004-3

DiMichele, W.A., Cecil, C.B., Montañez, I.P. \& Falcon-Lang,
H.J. 2010. Cyclic changes in Pennsylvanian paleoclimate and effects on floristic dynamics in tropical Pangea. International Journal of Coal Geology 83, 329-344.

DOI 10.1016/j.coal.2010.01.007

DiMichele, W.A., Chaney, D.S., Nelson, W.J., Lucas, S.G., Looy, C.V., Quick, K. \& WANG, J. 2007. A low diversity, seasonal tropical landscape dominated by conifers and peltasperms: Early Permian Abo Formation, New Mexico. Review of Palaeobotany and Palynology 145, 249-273.

DOI 10.1016/j.revpalbo.2006.11.003

DiMichele, W.A., Kerp, H., Krings, M. \& Chaney, D.S. 2005. The Permian peltasperm radiation: evidence from the southwestern United States, 67-79. In LuCAS, S.G. \& ZeIgler, K.E. (eds) The Nonmarine Permian. New Mexico Museum of Natural History and Science Bulletin 30.

DOI 10.1016/j.palaeo.2008.06.006

DiMichele, W.D., Kerp, H., Sirmons, R., Fedorko, N., Skema, V., BlaKe, B.M. JR. \& CECIL, B. 2013. Callipterid peltasperms of the Dunkard Group, Central Appalachian Basin. International Journal of Coal Geology 119, 56-78.

DOI 10.1016/j.coal.2013.07.025

DiMichele, W.A., Kerp, H., Tabor, N.J. \& LoOy, C.V. 2008. The so-called Paleophytic-Mesophytic transition in equatorial Pangea - Multiple biomes and vegetational tracking of climate change through geological time. Palaeogeography Palaeoclimatology Palaeoecology 268, 152-163.

DiMichele, W.A., Mamay, S.H., Chaney, D.S., Hook, R.W. \& NeLson, W.J. 2001. An Early Permian flora with Late Permian and Mesozoic affinities from North-Central Texas. Journal of Paleontology 75, 449-460.

DOI $10.1017 / \mathrm{S} 0022336000018230$,

DOI 10.1666/0022-3360(2001)075<0449:AEPFWL>2.0.CO;2

DiMichele, W.A., Montañez, I.P., Poulsen, C.J. \& Tabor, N.J. 2009. Climate and vegetational regime shifts in the late Paleozoic ice age earth. Geobiology 7, 200-226. DOI 10.1111/j.1472-4669.2009.00192.x

DiMichele, W.A., Tabor, N.J., Chaney, D.S. \& Nelson, W.J. 2006. From wetlands to wet spots: environmental tracking and the fate of Carboniferous elements in Early Permian tropical floras, 223-248. In Greb, S.F. \& DiMichele, W.A. (eds) Wetlands Through Time. Geological Society of America Special Publication 399.

Driese, S.G. \& Ober, E.G. 2005. Paleopedologic and paleohydrologic records of precipitation seasonality from Early Pennsylvanian "underclay" paleosols, U.S.A. Journal of Sedimentary Research 75, 997-1010. DOI 10.2110/jsr.2005.075

EDAX 2003. Genesis Spectrum User's Manual. 122 pp. Edax Inc., Mahwah.

Falcon-Lang, H.J., Jud, N.A., Nelson, W.J., DiMichele, W.A., Chaney, D.S. \& Lucas, S.G. 2011. Pennsylvanian coniferopsid forests in sabkha facies reveal the nature of seasonal tropical biome. Geology 39, 371-374. DOI 10.1130/G31764.1

Falcon-Lang, H.J., KurZawe, F. \& LuCas, S. 2014. Coniferopsid tree trunks preserved in sabkha facies in the Permian (Sakmarian) Community Pit Formation in south-central New Mexico, U.S.A.: systematics and palaeoecology. Review of 
Palaeobotany and Palynology 200, 138-160.

DOI 10.1016/j.revpalbo.2013.09.004

Falcon-Lang, H.J., Nelson, W.J., Elrick, S., Looy, C.V., AmeS, P.R. \& DiMicheLE, W.A. 2009. Incised channel fills containing conifers indicate that seasonally dry vegetation dominated Pennsylvanian tropical lowlands. Geology 37, 923-926. DOI 10.1130/G30117A.1

Feistmantel, K. 1883. Die mittelböhmische Steinkohlenablagerung. Archiv für die naturwissenschaftliche Landes-Durchforschung von Böhmen. Geologische Abteilung 5(3), 1-100.

Fielding, C.R., Frank, T.D. \& Isbell, J.L. 2008. The Late Paleozoic ice age - A review of current understanding and synthesis of global climate patterns, 343-354. In Fielding, C.R., FRANK, T.D. \& IsbeLl, J.L. (eds) Resolving the Late Paleozoic Ice Age in Time and Space. Geological Society of America, Special Papers 441.

GARTNER, O. 1924. Afanitická žíla z permu boskovické brázdy. Př́roda 17, 409-411.

Gastaldo, R. A., Purkyñová, E., Šimưnek, Z. \& Schmitz, M.D. 2009. Ecological persistence in the Late Mississippian (Serpukhovian-Namurian A) megafloral record of the Upper Silesian Basin, Czech Republic. Palaios 24, 336-350.

DOI 10.2110/palo.2008.p08-084r

GeINITZ, H.B. 1865. Über einige seltene Versteinerungen aus der unteren Dyas und der Steinkohlen-Formation. Neues Jahrbuch für Minerologie, Geologie und Paläontologie 1865, 385-395.

Gibling, M.R. \& Rygel, M.C. 2008. Late Paleozoic cyclic strata of Euramerica: Recognition of Gondwanan glacial signatures during periods of thermal subsidence, 219-233. In Fielding, C.R., Frank, T.D. \& Isbell, J.L. (eds) Resolving the Late Paleozoic Ice Age in Time and Space. Geological Society of America Special Paper 441.

GoEPPERT, H.R. 1858. Ueber die Flora der permischen Formation (Murchison) oder des Kupfergebirges (Hausmann). Jahres-Bericht der Schlesischen Gesellschaft für vaterländische kultur 36, 39-41.

Gothan, W. 1912. Paläobotanik, 408-460. In Korschelt, E., Linck, G., Schaum, K., Simon, H.T., Verworn, M. \& Teichmann, W. (eds) Handwörterbuch der Naturwissenschaften. G. Fischer, Jena.

Gradstein, F.M., OGG, J.G., Schmitz, M.D. \& OGG, G.M. 2012. The Geological time scale 2012. 1176 pp. Elsevier, Amsterdam.

HAMmer, Ø., Harper, D.A.T. \& RyAn, P.D. 2001. PAST: paleontological statistics software package for education and data analysis. Palaeontologia Electronica 4, 1-9.

Havlena, V. 1955. Vývoj stratigrafie permokarbonských uhelných oblastí Čech a Moravy. 100 pp. Ústřední ústav geologický, Praha.

Havlena, V. 1964. Geologie uhelných ložisek II. 437 pp. Nakladatelství Československé akademie věd, Praha.

Havlena, V. \& Špinar, Z. 1956. Stratigrafie permských uloženin v území mezi Bačovem a Svitávkou na Moravě. Sborník Ústředního ústavu geologického 22, 7-48.

Heckel, P.H. 2008. Pennsylvanian cyclothems in Midcontinent North America as far-field effect of waxing and waning of
Gondwana ice sheets. In Fielding, C.R., Frank, T.D. \& IsBell, J.L. (eds) Resolving the Late Paleozoic Ice Age in time and Space. Geological Society of America Special Paper 441, 275-289. DOI 10.1130/2008.2441(19)

Helmhacker, R. 1866. Uebersicht der geologischen Verhältnisse der Rossitz-Oslavaner Steinkohlenformation. Jahrbuch der Kaiserlich-Königlichen Geologischen Reichsanstalt 16, 447-460.

Hingenau, O. 1852. Uebersicht der geologischen Verhältnisse von Mähren und Österreichisch-Schlesien. 83 pp. Carl Gerold, Wien.

Hmich, D., Schneider, J.W., Saber, H., Voigt, F. \& El Wartiti, M. 2006. New continental Carboniferous and Permian faunas of Morocco: implications for biostratigraphy, palaeobiogeography and palaeoclimate. In LuCAS, S.G., CASsinIs, G. \& SCHNeIDER, J.W. (eds) Non-Marine Permian Biostratigraphy and Biochronology. Geological Society, London, Special Publications 265, 297-324.

DOI 10.1144/gsl.sp.2006.265.01.14

Horton, D., Poulsen, C., \& Pollard, D. 2007. Orbital and $\mathrm{CO}_{2}$ forcing of late Paleozoic continental ice sheets. Geophysical Research Letters 34, L19708. DOI 10.1029/2007GL031188

International Chronostratigraphic Chart v2016/04 2016. http://www.stratigraphy.org/index.php/ics-chart-timescale.

Isbell, J.L., Henry, L.C., Gulbranson, E.L., Limarino, C.O., Fraiser, M.L., Кoch, Z.J., Ciccioli, P.L. \& Dineen, A.A. 2012. Glacial paradoxes during the Late Paleozoic Ice Age: evaluating the equilibrium line altitude as a control on glaciation. Gondwana Research 22, 1-19.

DOI 10.1016/j.gr.2011.11.005

JafFey, A.H., Flynn, K.F., Glendenin, L.E., Bentley, W.C., \& EssLING, A.M. 1971. Precision measurements of half-lives and specific activities of ${ }^{235} \mathrm{U}$ and ${ }^{238} \mathrm{U}$, Physical Review C 4, 1889-1906. DOI 10.1103/PhysRevC.4.1889

JAROŠ, J. 1962. Geologický vývoj a stavba boskovické brázdy. 195 pp. Ph.D. thesis, Charles University, Prague, Czech Republic.

KATZER, F. 1895. Vorbericht über eine Monographie der fossilen Flora von Rossitz in Mähren. Sitzungsberichte der Königlische Böhmischen, Gesellschaft der der Wissenschaften in Prag 24 (1895), 1-26.

KERP, H. 1988. Aspects of Permian palaeobotany and palynology. $\mathrm{X}$. The West- and Central European species of the genus Autunia Krasser emend. Kerp (Peltaspermaceae) and the form-genus Rhachiphyllum Kerp (Callipterid foliage). Review of Palaeobotany and Palynology 54, 249-360. DOI 10.1016/0034-6667(88)90017-6

KeRP, H. 1996. Post-Variscan late Paleozoic northern hemisphere gymnosperms: the onset to the Mesozoic. Review of Palaeobotany and Palynology 90, 263-285. DOI 10.1016/0034-6667(95)00087-9

KeRP, H. 2000. The modernization of landscapes during the Late Paleozoic-Early Mesozoic. Paleontological Society Papers 6, 80-113.

Klembara, J. 1997. The cranial anatomy of Discosauriscus Kuhn, a seymouriamorph tetrapod from the Lower Permian of the Boskovice Furrow (Czech Republic). Philosophical 
Transactions of the Royal Society of London B 352, 257-302. DOI 10.1098/rstb.1997.0021

Klembara, J. \& Bartík, I. 1999. The postcranial skeleton of Discosauriscus Kuhn, a seymouriamorph tetrapod from the Lower Permian of the Boskovice Furrow (Czech Republic). Earth and Environmental Science Transactions of The Royal Society of Edinburgh 90(4), 287-316. DOI 10.1017/S0263593300002649

Klembara, J. \& Meszaros, Š. 1992. New finds of Discosauriscus austriacus (Makowsky 1876) from the Lower Permian of Boskovice Furrow (Czecho-Slovakia). Geologica Carpathica 43(5), 305-312.

Kozur, H. 1980. Die Korrelation des Rotliegenden und Zechsteins von Mittel- und Westeuropa mit der marinen Standardgliederung. Geologisch-Paläontologische Mitteilungen 9(10), 355-371.

KRÁLíK, J. \& MALÝ, L. 1987. Tufogenní horniny permokarbonu jižní části boskovické brázdy, 96-101. In Rosické uhelné doly (ed) Problematika geologické stavby uhelných ložisek ve velkých hloubkách. ČSVTS, Zbýšov u Brna.

Kukalová, J. 1955. Permoedischia n.g. (Protorthoptera) a Moraviptera n.g. (Palaeodictyoptera) z moravského permu. Sborník Ústředního ústavu geologického, Oddíl paleontologický 21, 541-575.

Kukalová, J. 1959. On the Family Blattinopsidae Bolton, 1925 (Insecta, Protorthoptera). Rozpravy Československé akademie věd, Řada matematických a př́rodních věd 69(1), 1-27.

Kukalová, J. 1963. Permian Insects of Moravia. Part I Miomoptera. Sborník geologických věd, Paleontonologie 1, $7-52$.

Kukalová, J. 1964. Permian Insects of Moravia. Part II Liomopteridae. Sborník geologických věd, Paleontonologie 3, 3-118.

KukalovÁ, J. 1965. Permian Protelytroptera, Coleoptera and Protorthoptera (Insecta) of Moravia. Sborník geologických věd, Paleontonologie 6, 61-98.

KušTA, J. 1900. Další př́íspěvky k seznání středočeského karbonu a permu. Rozpravy České akademie císaře Františka Josefa pro vědy, slovesnost a umění, Tř́da I matematicko-přírodnická 9(39), 1-19.

Le Maitre, R.W. (ed.) 2002. Igneous rocks. A classification and glossary of terms. Recommendations of the International Union of Geological Sciences Subcommission on the Systematics of Igneous Rocks. 236 pp. Cambridge Univerity Press, Cambridge.

Lojka, R., Drábková, J., Zajíc, J., SÝkorová, I., Francư, J., BlÁhová, A. \& Grygar, T. 2009. Climate variability in the Stephanian B based on environmental record of the Mšec Lake deposits (Kladno-Rakovník Basin, Czech Republic). Palaeogeography Palaeoclimatology Palaeoecology 280, 78-93. DOI 10.1016/j.palaeo.2009.06.001

Lojka, R., Rosenau, N.A., Sidorinová, T. \& Strnad, L. 2016. Architecture, paleosols and cyclicity of the Middle-Late Pennsylvanian proximal fluvial system (Nýrany Member, Pilsen Basin, Czech Republic). Bulletin of Geosciences 91(1), 111-140. 10.3140/bull.geosci.1509

Looy, C.V., Kerp, H., Duinstee, I.A.P. \& DiMichele, W.A.
2014. The late Paleozoic ecological-evolutionary laboratory, a land-plant fossil record perspective. The Sedimentary Record 12, 4-10. DOI 10.2110/sedred.2014.4.4

Lucas, S.G., Barrick, J.E., Krainer, K. \& Schneider, J.W. 2016. Pennsylvanian-Permian boundary at Carrizo Arroyo, Central New Mexico. New Mexico Geological Society Guidebook, 67th Field Conference, Geology of the Belen Area, 303-311.

Lyons, P.C. \& DARRAH, W.C. 1989. Earliest conifers of North America: upland and/or paleoclimatic indicators? Palaios 4, 480-486. DOI 10.2307/3514592

MaLÝ, L. 1968. Keratofyrové žíly v permokarbonu boskovické brázdy. Zprávy o geologických výzkumech v roce 1966, 169-170.

MaLÝ, L. 1972. Vývoj karbonu a hlubinná stavba Boskovické brázdy, 195-209. In Havlena, V., PeŠEK, J. \& Spudil, J. (eds) Sborník I. uhelně geologické konference katedry ložiskové geologie prírodovědecké fakulty Karlovy university v Praze. PřF UK, Praha.

MaLÝ, L. 1993: Formování sedimentační pánve permokarbonu boskovické brázdy a vývoj svrchnostefanské sedimentace v rosicko-oslavanské pánvi, 87-99. In Přıchystal, А., ОвStovÁ, V. \& Suk, M. (eds) Geologie Moravy a Slezska. MZM, Brno.

Mattinson, J.M. 2005. Zircon U-Pb chemical abrasion ("CA-TIMS") method: combined annealing and multi-step partial dissolution analysis for improved precision and accuracy of zircon ages. Chemical Geology 220, 47-66.

DOI 10.1016/j.chemgeo.2005.03.011

McLean, N.M., Condon, D.J., Schoene, B. \& Bowring, S.A. 2015. Evaluating uncertainties in the calibration of isotopic reference materials and multi-element isotopic tracers (EARTHTIME Tracer Calibration Part II). Geochimica et Cosmochimica Acta 164, 481-501.

DOI 10.1016/j.gca.2015.02.040

Melichar, R. 1995. Tektonický význam boskovické brázdy. Geologické výzkumy na Moravě a ve Slezsku v roce 1994, 64-66.

Montañez, I.P. \& Poulsen, C.J. 2013. The Late Paleozoic Ice Age: an evolving paradigm. Annual Review of Earth and Planetary Sciences 41, 629-656.

DOI 10.1146/annurev.earth.031208.100118

Montañez, I.P., Tabor, N.J., Niemeier, D., DiMichele, W.A., Frank, T.D., Fielding, C.R., Isbell, J.L., BiRgenheier, L.P. \& RYGEL, M.C. 2007. $\mathrm{CO}_{2}$-forced climate and vegetation instability during Late Paleozoic deglaciation. Science 315, 87-91. DOI 10.1126/science.1134207

Nehyba, S. \& Mastalerz, K. 1997. Příspěvek k poznání jezerní sedimentace v boskovické brázdě. Geologický výzkum na Moravě a ve Slezsku v roce 1996, 71-72.

NĚMEJC, F. 1951. K výskytu Callipteridů v obzoru slojí rosicko-oslavanských a k otázce stárí tohoto slojového pásma. Sborník Ústředního ústavu geologického 18, 425-436.

NĚMEJC, F. 1953. Úvod do floristické stratigrafie kamenouhelných oblastí v ČSR. 173 pp. Nakladatelství Československé akademie věd, Praha.

Opluštil, S. \& ClEAL, C.J. 2007. A comparative analysis of some 
Late Carboniferous basins of Variscan Europe. Geological Magazine 144, 417-448. DOI 10.1017/S0016756807003330

OpluŠTIL, S., LOJKA, R., Rosenau, N.A., STRNAD, L. \& SÝKOROVÁ, I. 2015. Middle Moscovian climate of eastern equatorial Pangea recorded in paleosols and fluvial architecture. Palaeogeography Palaeoclimatology Palaeoecology 440, 328-352. DOI 10.1016/j.palaeo.2015.09.009

Opluštil, S., Schmitz, M., Cleal, C.J. \& Martínek, K. 2016 a. A review of the Middle-Late Pennsylvanian west European regional substages and floral biozones, and their correlation to the Global Time Scale based on new U-Pb ages. Earth Science Reviews 154, 301-335. DOI 10.1016/j.earscirev.2016.01.004

Opluštil, S., Schmitz, M., Kachlí, V. \& Štamberg, S. $2016 \mathrm{~b}$. Re-assessment of lithostratigraphy, biostratigraphy, and volcanic activity of the Late Paleozoic Intra-Sudetic, Krkonoše-Piedmont and Mnichovo Hradiště basins (Czech Republic) based on new U-Pb CA-ID-TIMS ages. Bulletin of Geosciences 91(2), 399-432.

DOI 10.3140/bull.geosci.1603

Opluštil, S., Šimúnek, Z., Zajíc, J. \& Mencl, V. 2013. Climatic and biotic changes around the Carboniferous/Permian boundary recorded in the continental basins of the Czech Republic. International Journal of Coal Geology 119, 114-151. DOI 10.1016/j.coal.2013.07.014

Pešek, J. 2004. Late Palaeozoic limnic basis and coal deposits of the Czech Republic. Folia Musei Rerum Naturalium Bohemiae Occidentalis, Geologica 1, 1-188.

Pešek, J., Holub, V., Jaroš, J., Malý, L., Martínek, K., Prouza, V., SPUdIL, J. \& TÁsLER, R. 2001. Geologie a ložiska svrchnopaleozoických limnických pánví České republiky. 244 pp. Český Geologický ústav, Praha.

Pešek, J., Opluštil, S., Kumpera, O., Holub, V. \& Skoček, V. 1998. Paleogeographic Atlas, Late Paleozoic and Triassic Formations, Czech Republic. 53 pp. Czech Geological Survey, Praha.

Pfefferkorn, H.W. \& Thomson, M.C. 1982. Changes in dominance patterns in Upper Carboniferous plant-fossil assemblages. Geology 10(12), 641-644.

DOI 10.1130/0091-7613(1982)10<641:CIDPIU >2.0.CO;2

Phillips, T.L., Peppers, R.A. \& DiMichele,W.A. 1985. Stratigraphic and interregional changes in Pennsylvanian coal swamp vegetation: environmental inferences. International Journal of Coal Geology 5, 43-109. DOI 10.1016/0166-5162(85)90010-2

PRANTL, F. 1943. Vzácný nález v moravském permokarbonu. Věda př́rodní 22(4), 93-97.

Přichystal, A. 1993. Vulkanismus v geologické historii Moravy a Slezska od paleozoika do kvartéru, 59-70. In Přichystal, A., Obstová, V. \& SuK, M. (eds) Geologie Moravy a Slezska: Sborník př́spěvků k 90. výročí narozeni prof. dr. K. Zapletala. Moravské zemské muzeum a Sekce geologických věd Př́rodovědecké fakulty Masarykovy university, Brno.

PřichYstal, A. 1994. Nové výskyty magmatických hornin v permu boskovické brázdy. Geologické výzkumy na Moravě a ve Slezsku v roce 1963(1), 60-62.

PšeničKa, J., Kerp, H., Opluštil, S., Elrick, S., DiMichele,
W.A., Bek, J., Nelson, W.J. \& Ames, P.R. 2011. Preliminary report on the earliest callipterid assignable to the morphogenus Rhachiphyllum Kerp from the late Moscovian (Asturian) Farmington Shale (Illinois Basin, USA), 105. In HÅkansson, E. \& Totter, J.A. (eds) Programme \& $a b$ stracts: the XVII International Congress on the Carboniferous and Permian. Geological Survey of Western Australia, Perth.

Reuss, A.E. 1854. Beträge zur geognostischen Kenntnis Mährens. Jahrbuch der Kaiserlich-Königlichen Geologischen Reichsanstalt 5, 659-765.

Rieger, Z. 1965. Nové fytopaleontologické nálezy v rosicko-oslavanské oblasti. Časopis pro mineralogii a geologii 10(1), 89-91.

RitTleR, J. 1853. Bemerkungen über das mährische Steinkohlengebirge und die Kohlengruben nächst Brünn in Mähren. Österreichische Zeitschrift Berg- und Hüttenwesen 1, 340-341, 345-347.

Roscher, M. \& Schneider, J.W. 2006. Permo-Carboniferous climate: Early Pennsylvanian to Late Permian climate development of central Europe in a regional and global context, 95-136. In Lucas, S.G., Cassinis, G. \& Schneider, J.W. (eds) Non-Marine Permian Biostratigraphy and Biochronology. Geological Society of London, Special Publications 265.

Rosenau, N.A., Tabor, N.J., Elrick, S.D. \& Nelson, W.J. 2013 a. Polygenetic history of paleosols in Middle-Upper Pennsylvanian cyclothems of the Illinois Basin, USA. I. Characterization of paleosol types and interpretation of pedogenic processes. Journal of Sedimentary Research 83, 606-636. DOI 10.2110/jsr.2013.50

Rosenau, N.A., Tabor, N.J., Elrick, S.D. \& Nelson, W.J. 2013 b. Polygenetic history of paleosols in Middle-Upper Pennsylvanian cyclothems of the Illinois Basin, USA. II. Integrating geomorphology, climate, and glacioeustasy. Journal of Sedimentary Research 83, 637-668. DOI 10.2110/jsr.2013.51

SchmitZ, M.D. \& DAvydov, V.I. 2012. Quantitative radiometric and biostratigraphic calibration of the global Pennsylvanian Early Permian time scale. Geological Society of America Bulletin 124, 549-577. DOI 10.1130/B30385.1

Schmitz, M.D. \& Schoene, B. 2007. Derivation of isotope ratios, errors and error correlations for U-Pb geochronology using ${ }^{205} \mathrm{~Pb}-{ }^{235} \mathrm{U}-\left({ }^{233} \mathrm{U}\right)$-spiked isotope dilution thermal ionization mass spectrometric data: Geochemistry, Geophysics, Geosystems 8, Q08006. DOI 10.1029/2006GC001492

SCHNEIDER, J.W. 1980. Zur Entomofauna des Jungpaläozoikums der Boskovicer Furche (ČSSR), Teil 1: Mylacridae (Insecta, Blattoidea). Freiberger Forschungshefte C 357, 43-55.

SCHNEIDER, J.W. 1983. Die Blattodea (Insecta) des Paläozoikum. Teil I: Systematik, Ökologie und Biostratigraphie. Freiberger Forschungshefte. C 382, 106-145.

SCHNEIDER, J.W. 1984. Zur Entomofauna des Jungpaläozoikums der Boskovicer Furche (ČSSR), Teil 2: Phyloblattidae (Insecta, Blattoidea). Freiberger Forschungshefte, C 395, 19-37.

Schneider, J.W. \& Scholtze, F. 2016. Late Pennsylvanian-Early Triassic conchostracan biostratigraphy: a preliminary ap- 
proach. In Lucas, S.G. \& ShEn, S.Z. (eds) The Permian Timescale. Geological Society of London, Special Publications 450.

SCHNEIDER, J.W. \& Werneburg, R. 2006. Insect biostratigraphy of the European late Carboniferous and early Permian, 325-336. In Lucas, S.G., Cassinis, G. \& Schneider, J.W. 2006 (eds) Non-marine Permian biostratigraphy and biochronology. Geological Society of London, Special Publications 265. DOI 10.1144/sp450.6

Schneider, J.W. \& Werneburg, R. 2012. Biostratigraphie des Rotliegend mit Insekten und Amphibien, 110-142. In LÜTZNer, H. \& KowalczyK, G. (eds) Deutsche Stratigraphische Kommission: Stratigraphie von Deutschland X. Rotliegend. Teil I: Innervariscische Becken. Schriftenreihe der Deutschen Gesellschaft für Geowissenschaften 61.

SChNeIDER, J.W. \& ZaJíc, J. 1994. Xenacanthiden (Pisces, Chondrichthyes) des mitteleuropäischen Oberkarbon und Perm - Revision der Originale zu Goldfuss 1847, Beyrich 1848, Kner 1867 und Fritsch 1879-1890. Freiberger Forschungshefte C 452, 101-151.

Schneider, J.W., Körner, F., Roscher, M. \& Kroner, U. 2006. Permian climate development in the northern peri-Tethys area- the Lodève basin, French Massif Central, compared in a European and global context. Palaeogeography, Palaeoclimatology, Palaeoecology 240, 161-183.

DOI 10.1016/j.palaeo.2006.03.057

Schneider, J.W., Lucas, S.G. \& BARrick, J.E. 2013. The Early Permian age of the Dunkard Group, Appalachian basin, U.S.A., based on spiloblattinid insect biostratigraphy. International Journal of Coal Geology 119, 88-92.

DOI 10.1016/j.coal.2013.07.019

Schneider, J.W., Opluštil, S. \& Scholtze, F. 2014. CPC-2014 Field Meeting on Carboniferous and Permian Nonmarine Marine Correlation, Freiberg. Excursion Guide. Wissenschaftliche Mitteilungen 46, 1-121.

ŠEtLík, J. 1951. Paleontologicko-stratigrafické výzkumy ve stefanienu středních Čech a Moravy. Sborník Ústředního ústavu geologického 18, 437-448.

ŠIMƯNeK, Z. 2003. Fytopaleontologické výzkumy v Boskovické Brázdě. Zprávy o geologických výzkumech v roce 2002, $150-151$.

ŠImŮneK, Z. \& MartíneK, K. 2009. A study of Late Carboniferous and Early Permian plant assemblages from the Boskovice Basin, Czech Republic. Review of Palaeobotany and Palynology 155, 275-307.

DOI 10.1016/j.revpalbo.2008.05.006

ŠPINAR, V. 1951. Stratigraficko-paleontologické výzkumy v okolí Bačova a Trávníka. Věstník Ústředního ústavu geologického 26, 1-3, 134-136.

ŠPINAR, V. 1952a. Revize některých moravských discosauriscidů (Labyrinthodontia). Rozpravy Ústředního ústavu geologického 15, 1-159.

ŠPINAR, V. 1952b. O nálezech moravských krytolebců. Vesmír 31, $50-51$.

ŠPINAR, V. 1959. Zpráva o paleontologických výzkumech v Boskovické brázdě. Zprávy o geologických výzkumech v roce 1957, 239-240.
Stacey, J.S. \& Kramers, J.D. 1975. Approximation of terrestrial lead isotope evolution by a two-stage model. Earth and Planetary Science Letters 26, 207-221.

DOI 10.1016/0012-821X(75)90088-6

Štamberg, S. 2007. Permo-Carboniferous Actinopterygians of the Boskovice Graben. Part 1. Neslovicella, Bourbonnella, Letovichthys, Elonichthys. 155 pp. Muzeum východních Čech v Hradci Králové, Hradec Králové.

ŠTAMBERG, S. 2013a. Knowledge of the Carboniferous and Permian actinopterygian fishes of the Bohemian Massif - 100 years after Antonín Frič. Acta Musei Nationalis Pragae, Serie B, Historia Naturalis 69(3-4), 159-181.

S̆TAMBERG, S. 2013b. Aeduellid fishes (Actinopterygii) of the Bohemian Massif (Czech Republic) across the Carboniferous-Permian boundary, 417-422. In LuCAS, S.G., DiMichele, W.A., Barrick, J.A., Schneider, J.W. \& Spielman, J.S. (eds) The Carboniferous-Permian Transition. New Mexico of Natural History and Science Bulletin 60.

S̆tamberg, S. 2014. Fossiliferous Early Permian horizons of the Krkonoše-Piedmont Basin and the Boskovice Graben (Bohemian Massif) in view of the occurrence of actinopterygians. Freiberger Forschungshefte C 548, 45-60.

ŠTAMBerg, S. \& ZAJíc, J. 2008. Carboniferous and Permian faunas and their occurence in the limnic basins of the Czech Republic. 224 pp. Muzeum východních Čech v Hradci Králové, Hradec Králové.

STUR, D. 1873. Hugo Rittler's Skizzen über das Rothliegenden in der Umgebung von Rossitz. Verhandlungen der Kaiserlich-Königlichen Geologischen Reichsanstalt Wien 2, $31-36$.

TABOR, N.J. \& Poulsen, C.J. 2008. Palaeoclimate across the Late Pennsylvanian-Early Permian tropical palaeolatitudes: a review of climate indicators, their distribution, and relation to palaeophysiographic climate factors. Palaeogeography Palaeoclimatology Palaeoecology 268, 293-310.

DOI 10.1016/j.palaeo.2008.03.052

Tabor, N.J. Montañez, I.P., Scotese, C.R., Poulsen, C.J. \& MACK, G.H. 2008. Paleosol archives of environmental and climatic history in paleotropical western Pangea during the latest Pennsylvanian throughout Permian. Geological Society of America, Special Paper 441, 291-303.

TAndon, S.K. \& Gibling, M.R. 1994. Calcrete and coal in late Carboniferous cyclothems of Nova Scotia, Canada: Climate and sea-level changes linked. Geology 22, 755-758. DOI 10.1130/0091-7613(1994)022<0755:CACILC $>2.3 . C O ; 2$

TAYlor, N.T., TAYlor, E.L. \& Krings, M. 2009. Paleobotany. The Biology and Evolution of Fossil Plants. Second Edition. 1230 pp. Elsevier, Amsterdam.

WAGNER, R.H. 1984. Megafloral zones of the Carboniferous. Compte rendu 9e Congrès International de Stratigraphie et de Géologie du Carbonifère (Washington, 1979) 2, 109-134.

Wagner, R.H. \& Álvarez-Vázquez, C. 2010. The Carboniferous floras of the Iberian Peninsula: a synthesis with geological connotations. Review of Palaeobotany and Palynology 162, 239-324. DOI 10.1016/j.revpalbo.2010.06.005

Weithofer, K.A. 1902. Geologische skizze des Kladno-Rako- 
nitzer Kohlenbeckens. Verhandlungen der KaiserlichKöniglichen Geologischen Reichsanstalt 31, 399-420.

Weithofer, K.A. 1903. Die geologischen Verhältnisse der Steinkohlenablagerungen Böhmens. Allgemeine Bergmännische Zeitschrift Wien, 1-16.

ZAJíc, J. 2000. Vertebrate zonation of the non-marine Upper Carboniferous-Lower Permian basins of the Czech Republic. Courier Forschungsinstitut Senkenberg 223, 563-575.

Zajíc, J. 2004. Vertebrate biozonation of the Permo-Carboniferous lakes of the Czech Republic - new data. Acta Musei Reginaehradecensis, Série A 30, 15-16.

Zajíc, J. 2005. Permian acanthodians of the Czech Republic. Czech Geological Survey Special Paper 18, 1-42.

Zajíc, J. \& ŠTAmberG, S. 2004. Selected important fossiliferous horizons of the Boskovice Basin in the light of the new zoopaleontological data. Acta Musei Reginaehradecensis, Série A 30, 5-15.
Zajíc, J., Martínek, K., Šimưnek, Z. \& Drábková, J. 1996. Permokarbon boskovické brázdy ve výkopu pro rozšíření tranzitního plynovodu. Zprávy o geologických výzkumech $v$ roce $1995,158-159$.

ZaPletal, K. 1925. Keratofyru blízká žíla z permokarbonu oslavanského. Sborník Klubu př́rodovědeckého v Brně za rok 1924(7), 78-81.

Zapletal, K. \& Locker, F. 1930. Die Eruptivgänge im RossitzOslawaner Steinkohlengebiete. Montanistische Rundschau 22(13), 278-280.

ZIPPE, F.X.M. 1835. Die Flötzgebirge Böhmens mit besonder Rücksicht auf die Kohlenführung. Neue Schriften der Kaiserlichen Königlichen Patriotich-Ökonomischen Gesellschaft Böhmen 5, 1-49.

ZIPPE, F.X.M. 1842. Die Steinkohlen, ihr Werth, ihre Wichtigkeit im Allgemeinen ind ihre Verbreitung in Böhmen. Zeitschrift Gewerbewesen 2, 1-55. 